Atmos. Chem. Phys., 19, 11765-11790, 2019

https://doi.org/10.5194/acp-19-11765-2019

(C) Author(s) 2019. This work is distributed under

the Creative Commons Attribution 4.0 License.

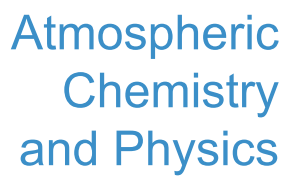

(c) (i)

\title{
In situ constraints on the vertical distribution of global aerosol
}

\author{
Duncan Watson-Parris ${ }^{1}$, Nick Schutgens ${ }^{2}$, Carly Reddington ${ }^{3}$, Kirsty J. Pringle ${ }^{3}$, Dantong Liu ${ }^{4}$, James D. Allan ${ }^{5,6}$, \\ Hugh Coe ${ }^{5}$, Ken S. Carslaw ${ }^{3}$, and Philip Stier ${ }^{1}$ \\ ${ }^{1}$ Atmospheric, Oceanic and Planetary Physics, Department of Physics, University of Oxford, Oxford, UK \\ ${ }^{2}$ Earth Sciences, Faculty of Science, Vrije Universiteit Amsterdam, Amsterdam, the Netherlands \\ ${ }^{3}$ School of Earth and Environment, University of Leeds, Leeds, UK \\ ${ }^{4}$ Department of Atmospheric Sciences, School of Earth Sciences, Zhejiang University, Hangzhou, Zhejiang, China \\ ${ }^{5}$ Centre for Atmospheric Science, SEAES, University of Manchester, Manchester, UK \\ ${ }^{6}$ National Centre for Atmospheric Science, University of Manchester, Manchester, UK
}

Correspondence: Duncan Watson-Parris (duncan.watson-parris@ physics.ox.ac.uk)

Received: 21 December 2018 - Discussion started: 7 February 2019

Revised: 21 July 2019 - Accepted: 26 July 2019 - Published: 23 September 2019

\begin{abstract}
Despite ongoing efforts, the vertical distribution of aerosols globally is poorly understood. This in turn leads to large uncertainties in the contributions of the direct and indirect aerosol forcing on climate. Using the Global Aerosol Synthesis and Science Project (GASSP) database - the largest synthesised collection of in situ aircraft measurements currently available, with more than 1000 flights from 37 campaigns from around the world - we investigate the vertical structure of submicron aerosols across a wide range of regions and environments. The application of this unique dataset to assess the vertical distributions of number size distribution and cloud condensation nuclei $(\mathrm{CCN})$ in the global aerosol-climate model ECHAM-HAM reveals that the model underestimates accumulation-mode particles in the upper troposphere, especially in remote regions. The processes underlying this discrepancy are explored using different aerosol microphysical schemes and a process sensitivity analysis. These show that the biases are predominantly related to aerosol ageing and removal rather than emissions.
\end{abstract}

\section{Introduction}

Atmospheric aerosol particles play a crucial role in the global energy balance by interacting with long-wave (LW) and short-wave (SW) radiation both directly and indirectly through aerosol-cloud interactions (ACIs). The direct radiative forcing due to aerosol particles depends on their scattering and absorption properties which are primarily determined by their refractive index, size and shape. The indirect forcing in liquid clouds (and to some degree of mixed-phase clouds; Heikenfeld et al., 2019) depends on the ability of aerosol particles to act as cloud condensation nuclei $(\mathrm{CCN})$, which in turn depends on the hygroscopicity and size distribution at the altitude of cloud droplet activation, which is mostly around cloud base at altitudes of $1-3 \mathrm{~km}$. Hence, constraining the global aerosol size distribution is a necessary (albeit insufficient) requirement for constraining both the direct and indirect aerosol forcing. In particular, the vertical distribution of aerosol, both natural and anthropogenic, can affect the magnitude of both of these effects (Samset et al., 2013; Marinescu et al., 2017).

Measurements of aerosol microphysical properties with good spatial coverage and reliability are vital for constraining the simulated aerosol properties in general circulation models (GCMs). However, currently available in situ measurement datasets have limited global representativeness - they do not equally sample all of the relevant aerosol regimes. The Cloud-Aerosol Lidar with Orthogonal Polarization (CALIOP; Winker et al., 2009) space-borne lidar provides unique information about the vertical distribution of cloud and aerosol globally and has been used in previous model evaluation studies (Koffi et al., 2012, 2016) but it is not possible to infer aerosol size information from the retrievals. Design constraints also mean that CALIOP is unable to detect background aerosol in the free troposphere because of the insufficient signal-to-noise ratio (Winker et al., 2013; Watson-Parris et al., 2018; Kacenelenbogen et 
al., 2011). The European Aerosol Research Lidar Network (EARLINET; Pappalardo et al., 2014) and NASA MicroPulse Lidar Network (MPLNET; Berkoff et al., 2004) ground station networks provide continent-scale lidar measurements and have been used in model evaluations (Ganguly et al., 2009; Satheesh et al., 2006) but these are unable to constrain remote aerosol conditions.

In situ aircraft measurements provide important direct measurements of aerosol chemical composition, size distributions and radiative properties anywhere in the troposphere. These measurements have been used extensively to investigate the representation of black carbon (BC) in GCMs (e.g. Koch et al., 2009; Schwarz et al., 2010; Kipling et al., 2013; Reddington et al., 2013), particle number (e.g. Spracklen et al., 2007; Yu et al., 2008; Mann et al., 2014; Dunne et al., 2016), organic aerosol (Heald et al., 2011) and also aerosol size distribution (Ekman et al., 2012). However, with some notable exceptions (e.g. Clarke and Kapustin, 2002), exploitation of aircraft measurements for global model evaluation has been restricted to a very small fraction of the available datasets, primarily because of the lack of easy access and a common data format. When using a selection of campaigns, it is also unlikely that these accurately represent the different global aerosol regimes. The Global Aerosol Synthesis and Science Project (GASSP) dataset (Reddington et al., 2017) brings together measurements from more than 1000 flights across 37 campaigns from around the world in a consistent, synthesised format. Using this combination of aircraft datasets, we are able to make more extensive evaluations of global climate models. In this paper, we use GASSP to evaluate the submicron aerosol and CCN distribution in ECHAM-HAM - an aerosol-climate model which includes explicit treatment of the aerosol size distribution and aerosol-cloud interactions.

The first focus of the paper is to illustrate the usefulness of a global aircraft dataset in evaluating aerosol in a GCM and some of the caveats and issues in doing so. While a large collection of aircraft measurements can provide extremely valuable information about aerosol microphysical properties, there are difficulties in using such data to evaluate a GCM. For example, aircraft in situ measurements represent a single point in space and time, whereas typical GCM output represents an average over a large $(\sim 100 \mathrm{~km})$ region and often days or months (Schutgens et al., 2016). We show that these sampling errors can be ensured to be small compared to model errors when the measurements are averaged over time and the high-temporal-resolution 4-D model fields are interpolated onto the measurement locations. The Community Intercomparison Suite (CIS) makes these interpolations straightforward even for fields on a hybrid sigma coordinate system (Watson-Parris et al., 2016).

The second focus is on characterising the vertical distribution of aerosol particles globally by combining these measurements with a GCM. We use one-at-a-time sensitivity tests of ECHAM-HAM model simulations and employ both the M7 modal and Sectional Aerosol module for Large Scale Applications (SALSA) bin microphysics (Kokkola et al., 2008) schemes to explore the processes controlling these distributions. We find that ECHAM-HAM represents the aerosol size distribution well in the boundary layer, but that it appears to underestimate accumulation-mode particles in the free-troposphere, which is also reflected in the $\mathrm{CCN}$ distribution. The wet deposition and ageing by sulfate condensational growth are both shown to play a crucial role in these biases.

In Sect. 2, we describe the GASSP dataset and ECHAMHAM model, before discussing the evaluation and sampling strategies in Sect. 3. We present the measurements and results from the evaluation in Sect. 4 and discuss their implications on constraining the global aerosol particle distribution in Sect. 5.

\section{Data}

\subsection{The GASSP dataset}

The GASSP dataset provides a global collection of in situ aerosol measurements from a large number of platforms in a single self-describing data format (Reddington et al., 2017). It includes measurements from more than 1000 flights and across 37 campaigns around the world - representing remote, continental and Arctic regions in the largest collection of data of its kind. All of the campaigns that included measurements of number size distribution or CCN are included in this evaluation, as detailed in Table 1 and shown in Fig. 1. The instruments providing aerosol size distributions (DMA, OPC, PILS, SMPS and FMPS) form the focus of the analysis (Sect. 4.1), while the CCN counter (CCNC) provides measurements of CCN used in Sect. 4.4, and sulfate measurements from the AMS instruments are used in Appendix C.

\subsection{Model description}

In this study, we use the ECHAM-HAMMOZ model as an example of a modern, well-characterised global aerosolclimate model in order to demonstrate the value of the GASSP dataset. While other models will likely show different behaviours and biases, it is hoped this initial evaluation will inform an extended analysis across a large number of models. The recently released ECHAM6.3-HAM2.3 version is used, which includes improved sea-salt and dust emission parameterisations and is described and evaluated in detail by Tegen et al. (2019) and Neubauer et al. (2019).

Briefly, the ECHAM6 atmospheric general circulation model (Stevens et al., 2013), which is developed by the Max Planck Institute for Meteorology in Hamburg, Germany, utilises a spectral transform dynamical core and a semi-Lagrangian tracer transport scheme in flux form (Lin and Rood, 1996). Convection is parameterised via the massflux schemes by Tiedtke (1989) and Nordeng (1994) and 
Table 1. Details of the campaigns and instruments included in the GASSP database that were used in this analysis. The environmental conditions summarise the prevailing conditions during the measurements; see associated references for more details.

\begin{tabular}{|c|c|c|c|c|}
\hline Campaign label & Aircraft & Season & Environmental conditions & Instrumentation \\
\hline $\begin{array}{l}\text { ACCACIA (Lloyd et al., } \\
\text { 2015; Young et al., 2016) }\end{array}$ & FAAM BAe-146 & Spring 2013 & - & $\mathrm{AMS}^{1}$ \\
\hline ACE1 (Clarke et al., 1998) & NCAR C-130 & SH summer 1995 & Marine, clean & $\begin{array}{l}\mathrm{DMA}^{2}+\mathrm{OPC}^{3} \\
\mathrm{CCNC}^{4}, \mathrm{PILS}^{5}\end{array}$ \\
\hline $\begin{array}{l}\text { ACEASIA (McNaughton et } \\
\text { al., 2004; Howell et al., } \\
\text { 2006) }\end{array}$ & NCAR C-130 & NH spring 2001 & $\begin{array}{l}\text { Asian outflow of dust, soot (biomass burning), } \\
\text { anthropogenic aerosol, anthropogenically } \\
\text { modified atmosphere, polluted marine }\end{array}$ & $\mathrm{DMA}^{6}+\mathrm{OPC}^{3}$ \\
\hline $\begin{array}{l}\text { AEGEAN-GAME } \\
\text { (Bezantakos et al., 2013) }\end{array}$ & FAAM BAe-146 & Summer 2011 & $\begin{array}{l}\text { Marine boundary layer, prevailing northern winds } \\
\text { (the Etesians), polluted air masses }\end{array}$ & SMPS $^{7}$, AMS $^{1}$ \\
\hline $\begin{array}{l}\text { APPRAISE (Crosier et al., } \\
\text { 2011) }\end{array}$ & FAAM BAe-146 & Winter 2009 & $\begin{array}{l}\text { Missions typically involved flight legs above and } \\
\text { below-cloud layers to characterise aerosol in the } \\
\text { vicinity of the clouds, and flight legs within cloud } \\
\text { to characterise cloud properties and attempt to } \\
\text { measure cloud particle residuals }\end{array}$ & $\mathrm{CCNC}^{8}$ \\
\hline $\begin{array}{l}\text { ARCPAC2008 (Brock et } \\
\text { al., 2011) }\end{array}$ & NOAA WP-3D & Spring 2008 & $\begin{array}{l}\text { Arctic haze, transport Asian pollution, } \\
\text { high-latitude biomass burning }\end{array}$ & $\mathrm{CCNC}^{8}, \mathrm{AMS}^{1}$ \\
\hline $\begin{array}{l}\text { ARCTAS (Jacob et al., } \\
\text { 2010) }\end{array}$ & $\begin{array}{l}\text { NASA P-3B + NASA } \\
\text { DC-8 }\end{array}$ & Spring, summer 2008 & $\begin{array}{l}\text { Arctic haze, boreal forest fires/biomass burning, } \\
\text { long-range transport of pollution to the Arctic }\end{array}$ & $\begin{array}{l}\mathrm{DMA}^{9}+\mathrm{OPC}^{10} \\
+\mathrm{CCNC}^{8}, \mathrm{AMS}^{11}\end{array}$ \\
\hline $\begin{array}{l}\text { BORTAS (Palmer et al., } \\
\text { 2013) }\end{array}$ & FAAM BAe-146 & Summer 2011 & Boreal forest fire, biomass burning & SMPS $^{7}, \mathrm{AMS}^{1}$ \\
\hline $\begin{array}{l}\text { CALNEX (Ryerson et al., } \\
\text { 2013) }\end{array}$ & NOAA WP-3D & Spring 2010 & $\begin{array}{l}\text { Polluted, urban plumes/emissions, ship } \\
\text { plumes/emissions, rural }\end{array}$ & $\mathrm{CCNC}^{8}, \mathrm{AMS}^{1}$ \\
\hline COPE (Leon et al., 2016) & FAAM BAe-146 & Summer 2013 & - & $\mathrm{SMPS}^{7}, \mathrm{AMS}^{1}$ \\
\hline DC3 (Barth et al., 2015) & NASA DC-8 & Spring, summer 2012 & $\begin{array}{l}\text { Midlatitude continental convective clouds, } \\
\text { convective storm inflow, convective transport of } \\
\text { fresh emissions }\end{array}$ & $\mathrm{CCNC}^{8}, \mathrm{AMS}^{11}$ \\
\hline EM25 & FAAM BAe-146 & Summer 2009 & $\begin{array}{l}\text { Urban polluted, direct sampling of emissions from } \\
\text { traffic on M25 motorway, in-plume sampling }\end{array}$ & $\mathrm{CCNC}^{8}$ \\
\hline $\begin{array}{l}\text { EUCAARI (Hamburger et } \\
\text { al., 2011) }\end{array}$ & FAAM BAe-146 & Spring 2008 & Polluted, high-pressure system, ageing pollution & $\mathrm{CCNC}^{8}, \mathrm{AMS}^{11}$ \\
\hline $\begin{array}{l}\text { GoAmazon (Martin et al., } \\
\text { 2016) }\end{array}$ & $\begin{array}{l}\text { ARM Aerial Facility (AAF) } \\
\text { Gulfstream-1 (G-1) }\end{array}$ & Dry season 2014 & $\begin{array}{l}\text { Pollutant outflow from a tropical megacity, ur- } \\
\text { ban plume sampling, evolution of properties along } \\
\text { the Manaus plume, persistent easterly winds, sam- } \\
\text { pling pristine and polluted air masses, sampling } \\
\text { changes to gases and particles within detrainment } \\
\text { levels of shallow cumulus clouds }\end{array}$ & $\mathrm{CCNC}^{8}$ \\
\hline $\begin{array}{l}\text { INDOEX (Twohy et al., } \\
\text { 2001; Clarke et al., 2002) }\end{array}$ & NCAR C-130 & NH Winter 1999 & $\begin{array}{l}\text { Polluted air from Indian subcontinent blown by } \\
\text { low-level winds over Arabian Sea and south of the } \\
\text { Equator }\end{array}$ & $\mathrm{OPC}^{3}, \mathrm{CCNC}^{4}$ \\
\hline $\begin{array}{l}\text { INTEX-A (Clarke et al., } \\
\text { 2007) }\end{array}$ & NASA DC8 & Summer 2004 & $\begin{array}{l}\text { Inflow and outflow of pollution over North } \\
\text { America, continental pollution plumes, biomass- } \\
\text { burning plumes }\end{array}$ & $\begin{array}{l}\text { DMA + } \mathrm{OPC}^{3} \\
\text { PILS }^{12}\end{array}$ \\
\hline $\begin{array}{l}\text { INTEX-B (Singh et al., } \\
\text { 2009) }\end{array}$ & NCAR C-130 & Spring 2006 & Polluted, marine boundary layer & $\mathrm{CCNC}^{8}, \mathrm{AMS}^{11}$ \\
\hline $\begin{array}{l}\text { MIRAGE (DeCarlo et al., } \\
2008)^{13}\end{array}$ & NCAR C-130 & Spring 2006 & $\begin{array}{l}\text { Megacity urban pollution, coastal regions, } \\
\text { regional influence of Mexico City significant } \\
\text { relative to other regions }\end{array}$ & $\begin{array}{l}\text { FMPS }^{14}, \mathrm{CCNC}^{8}, \\
\mathrm{AMS}^{11}\end{array}$ \\
\hline PASE (Clarke et al., 2013) & NCAR C-130 & Summer 2007 & $\begin{array}{l}\text { Focus on chemistry and physics (primarily of } \\
\text { sulfur) in a cloud-free convective boundary layer } \\
\text { of the Pacific Ocean }\end{array}$ & $\begin{array}{l}\mathrm{DMA}^{6}+\mathrm{OPC}^{3} \\
\mathrm{CCNC}^{4}, \mathrm{AMS}^{11}\end{array}$ \\
\hline $\begin{array}{l}\text { PEM-Tropics A (Hoell et } \\
\text { al., 1999) }\end{array}$ & NASA P-3B & $\begin{array}{l}\text { NH summer, NH autumn, } \\
\text { southern-tropical dry } \\
\text { season } 1996\end{array}$ & $\begin{array}{l}\text { Marine air masses, campaign period is a time of } \\
\text { enhanced biomass burning in the Southern Hemi- } \\
\text { sphere and this influence was evident in the data }\end{array}$ & $\mathrm{DMA}^{2}+\mathrm{OPC}^{3}$ \\
\hline
\end{tabular}


Table 1. Continued.

\begin{tabular}{|c|c|c|c|c|}
\hline $\begin{array}{l}\text { PEM-Tropics B (Clarke et } \\
\text { al., 2001) }\end{array}$ & NASA P-3B & $\begin{array}{l}\text { NH winter, NH spring, } \\
\text { southern-tropical wet } \\
\text { season } 1999\end{array}$ & $\begin{array}{l}\text { Marine air masses, tropical marine boundary layer, } \\
\text { La Niña event, continental pollution outflow, long- } \\
\text { range transport of dust and combustion aerosol } \\
\text { plumes from the Asian continent (Clarke et al., } \\
\text { 2001) }\end{array}$ & $\mathrm{DMA}^{2}+\mathrm{OPC}^{3}$ \\
\hline $\begin{array}{l}\text { RONOCO (Walker et al., } \\
\text { 2015) }\end{array}$ & FAAM BAe-146 & Summer 2010 & $\begin{array}{l}\text { The majority of the flying took place at night, with } \\
\text { occasional flights beginning or ending in daylight } \\
\text { hours to study chemical behaviour at dusk and } \\
\text { dawn, urban pollution }\end{array}$ & $\mathrm{CCNC}^{8}, \mathrm{AMS}^{11}$ \\
\hline $\begin{array}{l}\text { SEAC4RS (Toon et al., } \\
\text { 2016) }\end{array}$ & NASA DC-8 & Summer, autumn 2013 & $\begin{array}{l}\text { Polluted air masses, sampling wildfire/biomass- } \\
\text { burning plumes in western US, e.g. the Rim Fire, } \\
\text { sampling natural summertime emissions of iso- } \\
\text { prene from forests in the southeast US, deep con- } \\
\text { vective outflow and clouds }\end{array}$ & $\mathrm{CCNC}^{8}, \mathrm{AMS}^{11}$ \\
\hline $\begin{array}{l}\text { TEXAQS2006 (Parrish et } \\
\text { al., 2009; Asa-Awuku et al., } \\
\text { 2011) }\end{array}$ & NOAA WP-3D & Summer, autumn 2006 & $\begin{array}{l}\text { Polluted, near the end of the summer photo- } \\
\text { chemical ozone production season, majority of } \\
\text { flights occurred in Houston urban and industrial } \\
\text { ship-channel area, aircraft sampled urban outflow } \\
\text { from Dallas; other major targets included power } \\
\text { plants and various industrial plumes in east Texas; } \\
\text { biomass-burning plumes were sampled on a few } \\
\text { occasions }\end{array}$ & $\mathrm{CCNC}^{8}, \mathrm{AMS}^{11}$ \\
\hline $\begin{array}{l}\text { TROMPEX (Andrews et } \\
\text { al., 2013) }\end{array}$ & FAAM BAe-146 & Summer, autumn 2009 & Marine air masses & $\mathrm{CCNC}^{8}$ \\
\hline $\begin{array}{l}\text { VOCALS (Wood et al., } \\
\text { 2011) }\end{array}$ & NCAR C-130 & $\begin{array}{l}\text { NH autumn, southern } \\
\text { tropical dry season } 2008\end{array}$ & $\begin{array}{l}\text { Marine air masses, continental pollution outflow, } \\
\text { large stratocumulus cloud deck }\end{array}$ & $\begin{array}{l}\mathrm{DMA}^{6}+\mathrm{OPC}^{3} \\
\mathrm{CCNC}^{15}, \mathrm{AMS}^{11}\end{array}$ \\
\hline $\begin{array}{l}\text { VOCALS (Wood et al., } \\
\text { 2011) }\end{array}$ & FAAM BAe-146 & As above & As above & $\begin{array}{l}\mathrm{SMPS}^{7}, \mathrm{CCNC}^{8}, \\
\mathrm{AMS}^{11}\end{array}$ \\
\hline
\end{tabular}

${ }^{1}$ Aerodyne aerosol mass spectrometer C-ToF (Canagaratna et al., 2007; Drewnick et al., 2005). ${ }^{2}$ Radial differential mobility analyser (RDMA) is a small custom-built disk DMA (Zhang et al., 1995) with particle sizing set at $0.01-0.25 \mu \mathrm{m}$ using a TST model 3010 with $22^{\circ} \mathrm{C}$ saturator temperature difference for lowered detection limit and with thermal analysis similar to the OPC. ${ }^{3}$ Laser optical particle counter (OPC) (Particle Measurement Systems LAS-X, Boulder, Colorado, with customised electronics) effectively sizes particles between 0.100 and $14 \mu \mathrm{m}$ with a resolution of 112 logarithmically spaced channels per decade (Clarke, 1991$)$. Desert Research Institute (DRI) instantaneous CCN spectrometer (Hudson, 1989). Parallel plate thermal gradient diffusion cloud chamber with streamwise supersaturation gradient (each plate is divided into eight temperature controlled zones). ${ }^{5}$ The Georgia Institute of Technology particle-into-liquid sampling (PILS) system. ${ }^{6}$ NCAR radial differential mobility analyser system (NCAR RDMA) measured the size and number of particles between 0.007 and 0.150 um with a resolution of 54 channels per (Russell et al., 1996). ${ }^{7}$ Bespoke scanning mobility particle sizer (using TSI 3081 DMA, custom 3786 -LP WCPC, 4143 flowmeter). ${ }^{8}$ Droplet Measurement Technologies stream-wise thermal gradient continuous-flow CCN counter (Roberts and Nenes, 2010; Lance et al., 2006). ${ }^{9}$ Two custom DMAs (TDMA 0.01-0.20 $\mu \mathrm{m}$, LDMA 0.010-0.50 $\mu$ m mobility diameter). ${ }^{10}$ Optical particle counter (0.15-8.0 um optical diameter). ${ }^{11}$ High-resolution time-of-flight aerosol mass spectrometer (HR-ToF-AMS) (Canagaratna et al., 2007; DeCarlo et al., 2006). ${ }^{12}$ Particle-into-liquid diameter).
sampler coupled to ion chromatographs (ICs): one for the anions and one for the cations. ${ }^{13}$ Note that the MIRAGE campaign (more specifically MIRAGE-Mex) was designed to sample the heavily polluted air sampler coupled to ion chromatographs (ICs): one for the anions and one for the cations. ${ }^{13}$ Note that the MIRAGE campaign (more specifically MIRAGE-Mex) was designed to sample the heavily polluted air
downwind of Mexico City, Mexico, and as such introduced a large sampling bias when compared with the GCM area average (Tie et al., 2009). It was not included in the subsequent analysis. ${ }^{14}$ TSI fast mobility downwind of Mexico City, Mexico, and as such introduced a large sampling bias when compared with the GCM area average (Tie et al., 2009). It was not included in the subsequent
particle sizer (FMPS) spectrometer. ${ }^{15}$ University of Wyoming CCN instrument consists of a static thermal-gradient chamber and an optical detection system (Snider et al., 2006).

subgrid-scale stratiform clouds use the scheme of Sundqvist et al. (1989). While the base model uses a one-moment cloud microphysics scheme, ECHAM-HAM uses a two-moment cloud microphysics scheme (Lohmann et al., 2007; Lohmann and Hoose, 2009; Lohmann and Neubauer, 2018)

The microphysical aerosol model HAM (Stier et al., 2005; Zhang et al., 2012; Tegen et al., 2019) computes the evolution of an external mixture of internally mixed log-normal aerosol modes, considering the species sulfate, $\mathrm{BC}$, organic carbon (OC), sea salt and mineral dust. Coupled to ECHAM, the evolution of the log-normal modes, represented by aerosol mass and numbers, is computed taking into account physical and chemical particle processes. The microphysical core M7 (Vignati et al., 2004) calculates coagulation among the modes and the condensation of gas-phase sulfuric acid on the existing aerosol population. Aerosol particles are removed by sedimentation and dry and wet deposition. Gravitational sedimentation of particles is calculated based on their median size using the Stokes settling velocity (Seinfeld and Pandis, 1998), with a correction factor according to Slinn and Slinn (1980). Removal of aerosol particles from the lowest model layer by turbulence depends on the characteristics of the underlying surface (Zhang et al., 2012). The aerosol dry deposition flux is computed as the product of tracer concentration, air density and deposition velocity, depending on the aerodynamic and surface resistance for each surface type considered by ECHAM6.3, and subsequently added up for the fractional surface areas. For wet deposition, the in-cloud scavenging scheme from Croft et al. (2010), dependent on the wet particle size, is used. The in-cloud scavenging scheme takes into account scavenging by droplet activation and impaction scavenging in different cloud types, distinguishing between stratiform and convective clouds and warm, cold and mixed-phase clouds. Below clouds, particles are scavenged by rain and snow using a size-dependent below-cloud scavenging scheme (Croft et al., 2009). Scavenged particles can also be resuspended by the evaporation of precipitation (Stier et al., 2005). In turn, the effects of aerosols on clouds and radiation are computed prognostically in the coupled ECHAM-HAM. The relative importance of the individual aerosol processes in ECHAM-HAM has been evaluated by 
Schutgens and Stier (2014) and informs the choice of parameters used for the sensitivity analysis in this work.

In this work, the model is run at T63 resolution with 31 vertical levels and nudged to ERA-Interim reanalysis for 2008 (Dee et al., 2011), using the Atmospheric Chemistry and Climate Model Intercomparison Project (ACCMIP) interpolated emission dataset (Lamarque et al., 2010). The use of a single model year to compare against the multi-year GASSP dataset and its implications for the evaluation are discussed in Sect. 3.

In order to explore the uncertainty in the vertical structure of the aerosol size distribution, we perform a set of sensitivity simulations in which key parameters were scaled up and down one at a time. There are dozens of parameters and processes which affect the aerosol number at any given location (e.g. Lee et al., 2013) but this analysis aims to cover the main processes which would be expected to affect the relative biases in size distribution discussed in Sect. 4.1, particularly focussed around aerosol growth, removal and vertical transport. There are some processes which might be expected to affect these biases which are not represented in the model at all such as prognostic in-cloud aerosol processing (Hoose et al., 2008), aerosol removal by photolysis (Hodzic et al., 2015) and interactive secondary organic aerosol (SOA) formation (e.g. Heald et al., 2011). For example, the use of prescribed SOAs has been shown to result in a lower SOA burden compared to online calculation (Tegen et al., 2019). This has also been shown to have a large effect on the vertical distribution of organic aerosol in other models (e.g. Shrivastava et al., 2015; Tsigaridis et al., 2014), although the exact impact on the vertically resolved aerosol size distribution considered in this work is not clear. While the contributions of these processes are not explored further here, such structural uncertainties will be the focus of a future multi-model experiment described in Sect. 5.

Having determined the processes to analyse, we apply a simple high/low perturbation over their likely range of uncertainty in order to determine their relative contribution to any model-measurement differences, as outlined in Table 2 and described in detail below. One-at-a-time sensitivity tests neglect the important effects of combinations of parameter perturbations that are captured by Latin hypercube perturbed parameter ensemble studies (e.g. Lee et al., 2013; Regayre et al., 2018). However, they allow an assessment of how individual process parameter uncertainties contribute to the vertical profile of the aerosol size distribution and can be used as a screening test to determine important model processes for further analysis.

\subsubsection{Condensational ageing}

In the default HAM setup, a single monolayer of sulfate is assumed to be required to transfer insoluble particles to the corresponding soluble/mixed particle mode following (Vignati et al., 2004). There is considerable uncertainty in this simple approximation. We therefore vary the number of monolayers required from 0.3 to 5 , matching the ranges used by Lee et al. (2013).

\subsubsection{Wet deposition}

HAM2 includes wet deposition removal of aerosol via incloud nucleation and impaction scavenging as well as belowcloud impaction scavenging by rain and snow. In-cloud nucleation is the most important of these mechanisms and, because it primarily occurs at the top of the boundary layer, it has a large effect on the vertical distribution of aerosol (e.g. Kipling et al., 2016; Mahmood 2016). Here, we scale the total in-cloud and below-cloud mixing-ratio removal tendencies in each grid cell by a constant factor. As one of the primary aerosol removal mechanisms globally, the aerosol burdens are very sensitive to this scaling; so while there are large uncertainties in the precipitation and scavenging rates, the range of scalings used is smaller than in the other perturbations. Initial scaling values of 10, 5 and even 3 led to implausible aerosol burden globally.

\subsubsection{Vertical flux in convection}

Convection is one of the dominant mechanisms for transporting aerosol and trace gases from the boundary layer into the free troposphere globally (Park and Allen, 2015). There are large uncertainties in the aerosol entrainment and detrainment rates for convective clouds. Here, we scale the total convective tracer mass flux in each grid cell to sample this uncertainty. The large range in scale factors was chosen to reflect the large uncertainties in the fluxes and due to the relative insensitivity of the aerosol to this parameter.

\subsubsection{Coagulation}

The inter- and intramodal components of the standard coagulation kernel within the M7 aerosol scheme can be scaled independently to represent uncertainty in the assumptions used to calculate it, such as using only the median mode diameter in calculating the terms and uncertainties in the effects of turbulence and electrostatics. In this work, since we are interested only in the broad uncertainties, we scale the whole kernel by the same scale factor.

\subsubsection{Aerosol dry deposition}

Lee et al. (2013) showed that uncertainties in the dry deposition process provided the largest contribution to the uncertainty in CCN globally in the Hadley Centre Global Environmental Model - Global Model of Aerosol Processes (HadGEM-GLOMAP) GCM. Here, we scale the dry deposition velocities for the Aitken and accumulation modes across the same range as in their study. 


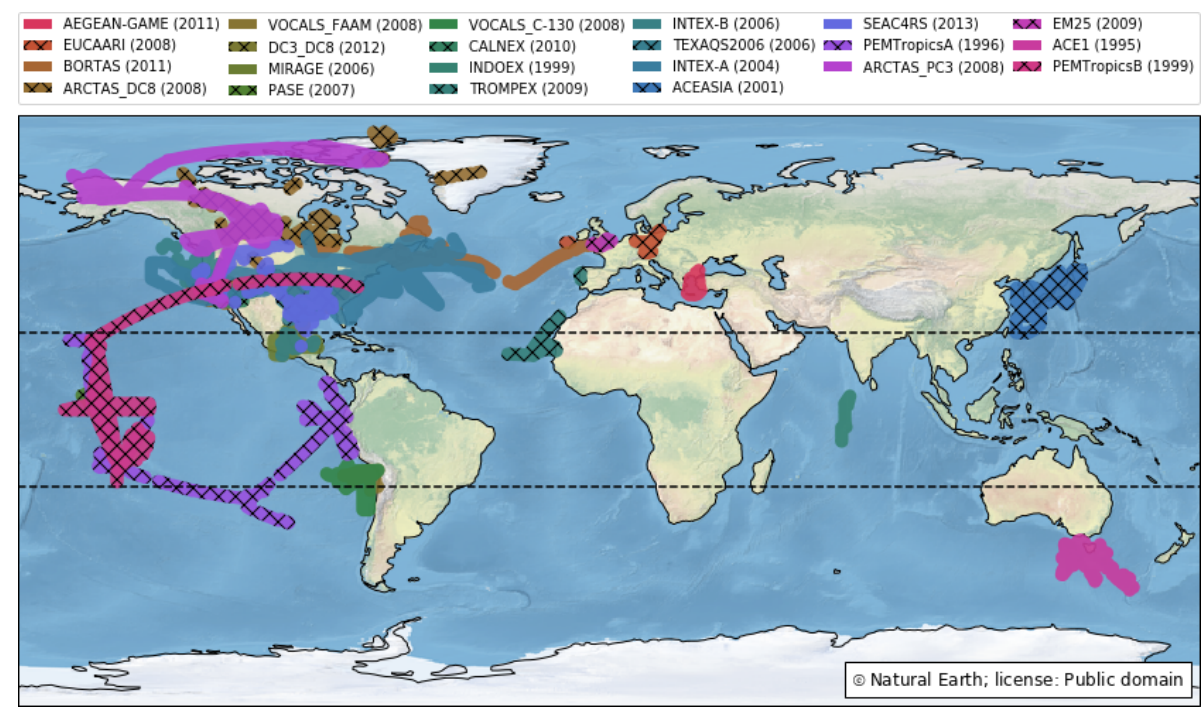

Figure 1. Spatial coverage of flight campaigns included in the GASSP database which include number size distribution or CCN measurements.

Table 2. Outline of the sensitivity experiments performed. The scale factors refer to the high and low multiplicative factors applied to the relevant model parameter. See text for details.

\begin{tabular}{llr}
\hline Parameter & Description of scaled quantity & Scale factor \\
\hline Condensational ageing & The number of layers of $\mathrm{SO}_{4}$ for a particle to be "coated" & $0.3-5.0$ \\
Wet deposition & In- and below-cloud wet deposition fluxes & $0.5-2.0$ \\
Vertical flux in convection & Convective tracer entrainment & $0.1-10.0$ \\
Coagulation & Probability of inter- and intramode coagulation & $0.5-2.0$ \\
Dry deposition (acc.) & Dry deposition of accumulation-mode aerosol & $0.1-10.0$ \\
Dry deposition (Ait.) & Dry deposition of Aitken-mode aerosol & $0.5-2.0$ \\
\hline
\end{tabular}

\section{Evaluation strategy}

The GASSP aircraft database provides valuable measurements with which to constrain global climate models. However, these near-instantaneous point measurements represent something quite different from typical model output fields which are often temporal averages of a grid cell which itself represents some (usually undefined) average over a large spatial region, typically $\sim 100 \mathrm{~km}$ in extent. The question of how to compare these two datasets consistently is the subject of this section.

Schutgens et al. (2016) show the importance of collocating measurements with high-temporal-resolution model fields in order to reduce the large temporal sampling artefacts which would otherwise be present. This has also been noted in previous model evaluation work using aircraft data (Ekman et al., 2012). Further work (Schutgens et al., 2017) showed the importance of averaging these collocated measurements over as long a period as possible in order to remove spatial sampling biases. While higher-spatial-resolution models would reduce this particular form of sampling bias, they would face the associated problem of small transport differences leading to large biases (Fast et al., 2016). Some campaigns include sampling biases by design, due to the particular objectives of the mission. For example, the MIRAGE campaign was flown to specifically measure the pollution downwind of Mexico City and hence overrepresents the mean aerosol loading in the (wider) region. As noted in Table 1, this campaign was not included in the subsequent analysis. Some recent flight campaigns, such as VOCALS (Wood et al., 2011) and ORACLES (Zuidema et al., 2016), fly routine tracks several times during the campaign specifically to build up representative spatial statistics for comparison with models; however, most historic campaigns have not.

A further complication in the use of the combined measurements from a variety of campaigns, aircraft and even instruments is that the measurements themselves will have different sampling rates and systematic biases (for example, due to the use of different inlets). Another concern is the different inlets and piping used to bring the sampled air inside the aircraft and to the instrumentation. Because these biases will generally be uncorrelated across campaigns, we assume that the large number of campaigns used will remove any systematic bias in the reported average size distributions. 
As discussed in Sect. 2.3, the model is run for a single year rather than the full observational period. Although the GASSP data span many years, the interannual variability in aerosol burden, away from the main biomass-burning regions, is small (Li et al., 2013). Further, the three oldest campaigns (ACE1 and PEM-Tropics A/B) sample remote ocean environments where the effect of any trends in anthropogenic emissions are expected to be small. Nevertheless, interannual variability and trends in meteorology, emissions and removal (through, e.g. precipitation) will introduce some uncertainty in our analysis.

In order to remove the most high-frequency variability in the measurements (which we would not expect the GCM to reproduce), to bring the measurements onto a common temporal sampling and to provide at least some temporal aggregation, we downsample the measurements to 2 min averages. Typical aircraft in the GASSP database, such as the NOAA P3-B and the FAAM BAe-146, have cruise speeds of 600$800 \mathrm{~km} \mathrm{~h}^{-1}$, so this averaging corresponds to a distance of $10-15 \mathrm{~km}$. Detailed investigations of spatial variability of aircraft aerosol measurements in the ARCTAS campaign (Shinozuka and Redemann, 2011) show that this length scale will average out local emission sources while still maintaining the long-range variability which we hope the GCM to reproduce.

Using CIS (http://www.cistools.net/, last access: 6 September 2019: Watson-Parris et al., 2016) to linearly interpolate the model fields of interest onto these temporally averaged measurements, we should minimise the associated sampling errors. The question remains, however, what model output frequency is required. The storage requirements for the 3-D model fields we wish to interpolate quickly become inhibiting for daily and subdaily model output.

Figure 2 shows the model $\mathrm{CCN}$ at $1 \%$ supersaturation output at different temporal frequencies interpolated onto the observation points over North America compared against the same model values used as output from an online flight-track simulator. This simulator provides the highest possible output frequency by interpolating arbitrary model fields onto a set of latitude/longitude/pressure points at every model output time step. The reduced correlation $(<0.7)$, high normalised bias $(<-0.15)$, decreased variability and large root mean square error (RMSE) introduced by interpolating monthly model output fields are clearly seen. Similar characteristics can be seen for the points over the south-east Pacific; however, in this case, the bias introduced is positive. Similar results can be obtained for other model fields all over the globe. Although the flight track simulator provides a powerful diagnostic capability, we use model data interpolated from 3-hourly output fields for the results presented in Sect. 4 as a compromise between the introduced sampling bias and convenience in analysis. As shown in Fig. 2, the bias and RMSE introduced are negligible.

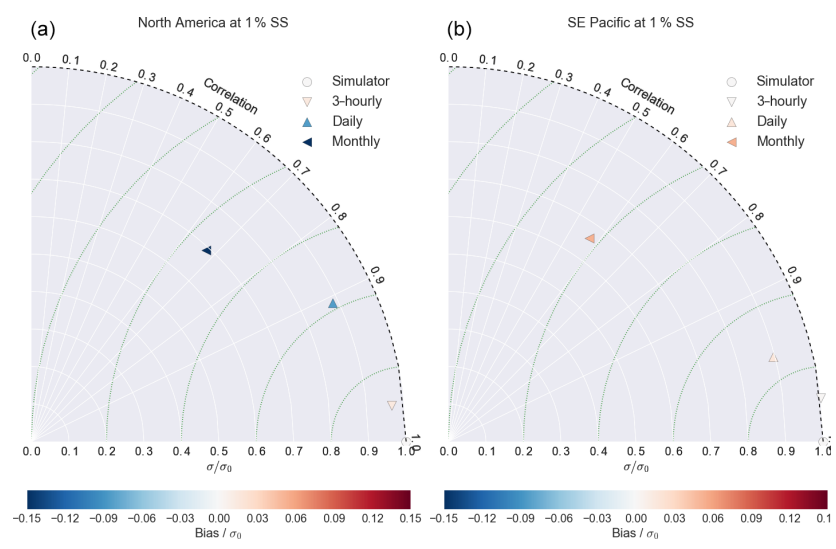

Figure 2. Taylor diagram showing the root mean square (rms) error and reduction in correlation and variability introduced by comparing instantaneous model output (using a flight track simulator) with interpolations from different temporal aggregations of the same model data. All datasets are linearly interpolated from the same underlying 4-D model field (CCN at $1 \%$ supersaturation) and compared with an online interpolation. Panel (a) shows points taken over North America; panel (b) shows points over the south-east Pacific.

\section{Results}

\subsection{Aerosol size distribution}

The aerosol size distribution can be characterised in several ways, for example, by aerosol number, surface area or volume. The Aitken and accumulation modes are most important for constraining the indirect effect, so we focus on the aerosol number size distribution (NSD): $n_{N}^{e}\left(\ln D_{\mathrm{P}}\right) \mathrm{d} \ln D_{\mathrm{p}}=$ number of (dry) particles per unit volume of (ambient) air in the size range $\ln D_{\mathrm{P}}$ to $\ln D_{\mathrm{P}}+\mathrm{d} \ln D_{\mathrm{P}}$

Figure 3 shows the median measured aerosol NSD from the GASSP database for all flights which included the relevant measurements, interpolated onto common aerosol diameters and binned into $0.5 \mathrm{~km}$ vertical bins. (Fig. A1 shows the number of observations in each altitude bin). A number of interesting features are apparent. The strong anthropogenic sources in the northern extratropics are clearly seen in the larger number of accumulation-mode aerosols in the boundary layer. The tropics show a similar number of aerosols in the free troposphere as the northern extratropics, apart from a clear increase in Aitken-mode aerosol at $8 \mathrm{~km}$, resulting from the growth of the significant number of nucleationmode aerosol in the upper troposphere-lower stratosphere (UTLS; Clarke and Kapustin, 2002; Stier et al., 2005). The aerosol distribution in the southern extratropics is noticeably smaller than in the tropics or northern extratropics with more aerosol residing in the Aitken mode, partly due to the lower tropopause height at midlatitudes affecting the UTLS nucleation-mode aerosol described above. The lower number of accumulation-mode aerosol in the Southern Hemisphere 


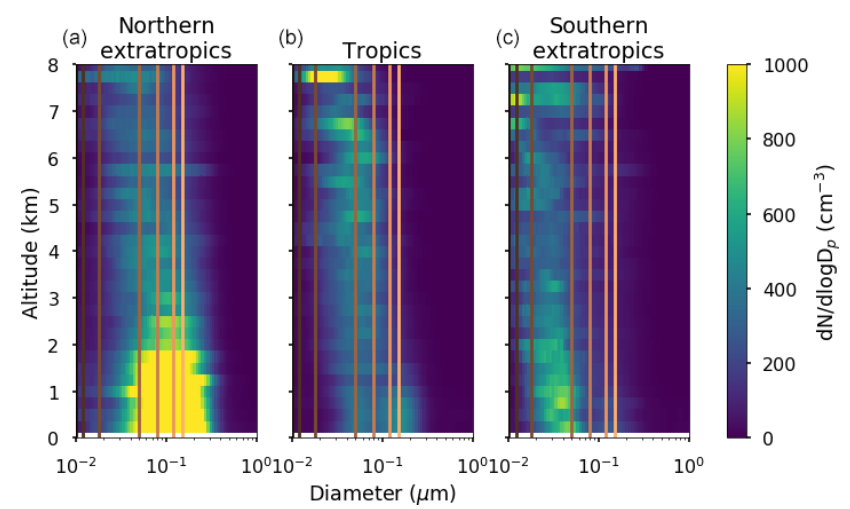

Figure 3. The median aerosol number size distribution observed at each altitude across all flights in the northern extratropics (a), tropics (b) and southern extratropics (c). The copper lines represent the sizes from which the integrated numbers in, e.g. Fig. 4 are calculated.

has been observed before (e.g. Minikin et al., 2003) and is attributed to the lack of anthropogenic aerosol and gaseous precursor sources in the Southern Hemisphere.

For comparison between the modelled (modal) and observed (binned) aerosol distribution, it is useful to reduce this distribution to a single number representing the integrated number above some lower threshold:

$N_{S}=\int_{S}^{\infty} n_{N}\left(D_{\mathrm{P}}\right) \mathrm{d} D_{\mathrm{P}}$.

While $D_{\mathrm{P}}$ will often be plotted in units of micrometres, in this paper, $N_{S}$ is always an integrated number above diameter $S$ in nanometres.

We can interpolate the model mode number and radius fields onto the measurements and calculate $N_{S}$ across a range of sizes for each point. While the integrated number concentrations at smaller size cut-offs will include the number of larger-sized particles, the smallest particles will dominate the number. Figure $4 a$ and $b$ show the global average of these collocated, integrated numbers as a function of altitude. In this figure, we show the median and interquartile range of the global values in each altitude bin as this better represents the (log-skewed) distributions. We also then plot the fractional biases, defined as $\mathrm{FB}=\frac{\text { Model-Obs }}{(\text { Model }+ \text { Obs) } / 2}$, as shown in Fig. 4c. Profiles for each campaign and size cut-off are shown in Fig. C4.

The model performs best in the lower free troposphere with a near-zero bias around $1-3 \mathrm{~km}$, but it underestimates number concentrations in all aerosol size ranges in the planetary boundary layer (PBL). In the upper free troposphere (FT), above $4 \mathrm{~km}$, the model reproduces the number of particles smaller than around $10 \mathrm{~nm}$ very well, but there is a clear low bias of up to $100 \%$ in the number of larger (submicron) particles.
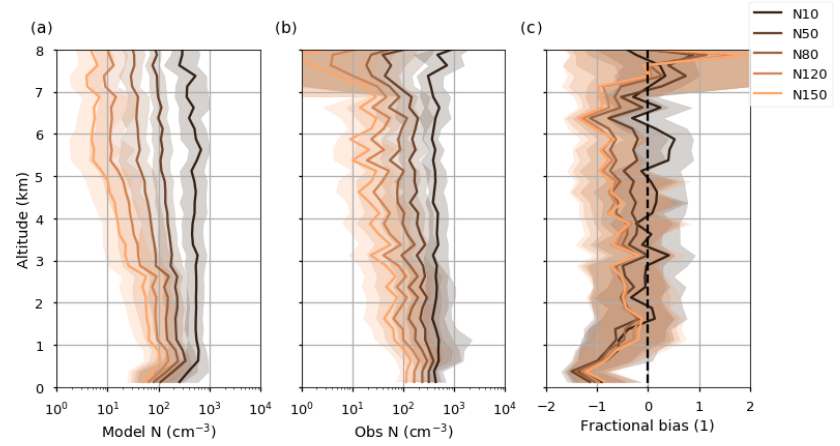

Figure 4. The vertical profile of integrated (a) model and (b) observed aerosol number at different size cut-offs. The lines represent the median over all points in that altitude bin, while the shading shows the interquartile range. Panel (c) shows the median fractional bias.

It should be noted that with the DMA-based instruments there is a potential for uncertainties associated with the assumed particle charging model. As part of their inversions, these instruments must assume a probability that particles of a given size achieve the specified states when subjected to the bipolar charge field at the instrument's inlet (Liu and Pui, 1974). The most common method used is the parameterisation of Wiedensohler (1988), which has proven to be robust in most applications (Wiedensohler et al., 2012). More recently, fundamental modelling studies have investigated how much this function depends on conditions such as particle composition, temperature and pressure and have suggested these effects may be important in some situations (LópezYglesias and Flagan, 2013). In principle, if the charging function were to vary with pressure, this could be responsible for systematic artefacts in the vertical profiles of particle concentrations presented here. Leppä et al. (2017) presented a case study at $10 \mathrm{~km}$ altitude and suggested that the number concentrations of particles greater than $10 \mathrm{~nm}$ diameter would be underreported by between $5 \%$ and $33 \%$ depending on the ambient size distribution and other technical details such as the polarity of the instrument. However, at the time of writing, we are not in a position to use this result as the basis for a correction for our data because the altitude dependency case studies of López-Yglesias and Flagan (2013) and Leppä et al. (2017) varied both temperature and pressure simultaneously according to typical ambient conditions. In contrast, the instruments whose data are being used here charged the aerosols at aircraft cabin temperature rather than ambient, so the actual effect that pressure variations may be having on the data is currently uncertain. Because applying a systematic correction would be both technically challenging and computationally expensive, this is deemed outside the scope of this work; however, in the event that a generalised correction method be developed in the future, this issue should be revisited. Taken at face value, however, this would mean our measured data of particles larger than $10 \mathrm{~nm}$ 
would be at worst biased low a few tens of percent at altitude, which would in turn only make the reported model biases more significant. Note also that this uncertainty relates to how many particles get charged (and hence counted), but once charged the size of the aerosol can still be accurately determined; hence, this issue only affects counting and not the sizing of particles. The effects of variations in pressure and temperature on DMA sizing are already well established and accounted for (Knutson and Whitby, 1975).

In order to understand the source of these global model biases, we can split the data into measurements made over land or ocean, roughly analogous to near/far from major sources, respectively, in order to understand the role of emissions and removal in the model bias. Figure 5 shows the fractional bias in modelled aerosol number over land and ocean. The vertical profile of the bias over land shows the model consistently underestimates aerosol across all sizes in these regions. This bias is largest in the boundary layer where biases due to the sampling of local emissions sources not resolved by the coarse model resolution are likely to be dominant. The bias in the smaller particles improves with altitude and is near zero above $6 \mathrm{~km}$. The larger particles however show the same bias as in the global mean above $4 \mathrm{~km}$. The ocean profiles generally show much better agreement with the measurements throughout the troposphere, although the bias in the number concentration of large particles in the free troposphere remains. In these generally more remote regions, the model recreates the overall aerosol number well but is underestimating the number of larger particles aloft - suggesting overefficient removal of these particles or insufficient growth. Figure 5 also shows a strong low bias in the near-surface aerosol number over the ocean for all aerosol sizes. This is (at least partly) due to insufficient $\mathrm{SO}_{4}$ in the ocean boundary layer, as shown in Fig. C1, presumably due to insufficient DMS emission. Insufficient emissions of marine organic aerosols and aerosol precursors could also contribute to this bias.

It is instructive to stratify by latitude. Figure 6 shows the fractional bias profiles for flights in the tropics and northern and southern extratropics. The northern extratropical profiles show similar biases to the overland biases shown in Fig. 5 since these include many of the same flights. Similarly, the tropical profiles are mostly over ocean. However, the most remote dataset in the southern extratropics (ACE1) has the strongest bias in the number of large particles.

\subsection{Sensitivity tests}

\subsubsection{Condensational ageing}

In HAM-M7, condensational ageing is the primary mechanism by which aerosol (mass and number) is transferred from the insoluble Aitken and accumulation modes into their soluble equivalents (Schutgens and Stier, 2014) where they become available for removal by nucleation scavenging. The current assumption in this model is to require one mono-

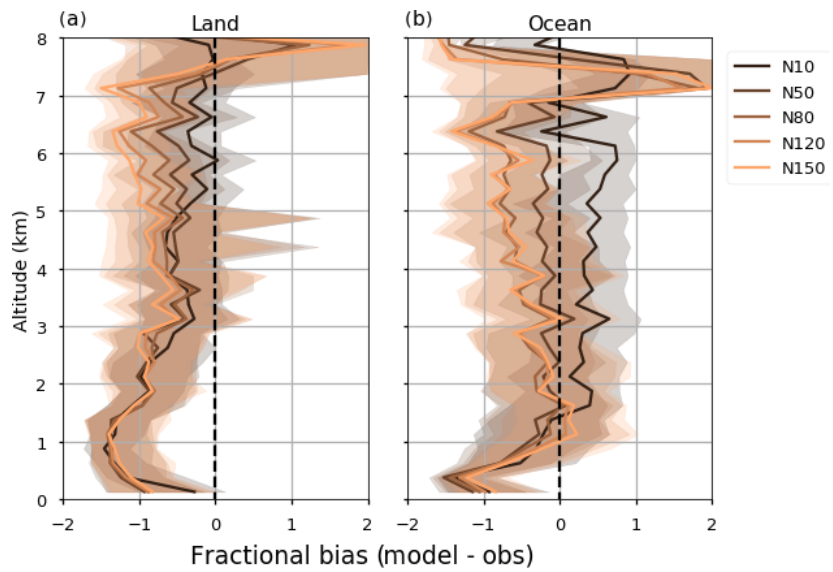

Figure 5. The vertical profile of fractional bias in modelled aerosol number at different size cut-offs for land (a) and ocean (b) measurements.

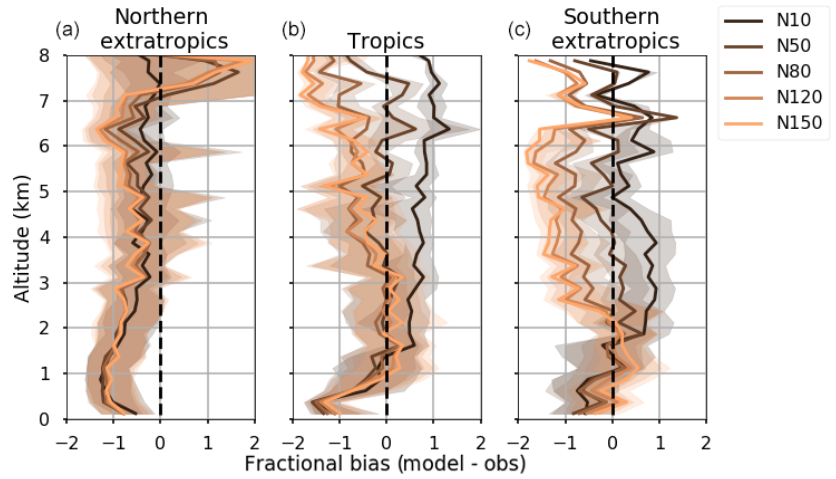

Figure 6. The vertical profile of fractional bias in modelled aerosol number at different size cut-offs for measurements in the northern extratropics (a), the tropics (b) and the southern extratropics (c).

layer of sulfate condensed on a particle to transfer it from the insoluble to soluble modes. Figure 7 shows profiles of fractional bias in each of the latitudinal ranges shown in Fig. 6 but with a reduced and increased amount of sulfate required, leading to faster and slower condensational ageing, respectively. Changing the condensational ageing rate between the values chosen for this study has a minimal effect in the tropical and southern extratropical regions. However, the slower condensational ageing profiles show a reduced negative bias in the number of larger particles in the northern extratropics (presumably by reducing their removal through scavenging), at the expense of an increase in the negative bias for smaller particles. Nearer the large anthropogenic sulfate sources in the Northern Hemisphere, ageing timescales are much shorter (Schutgens and Stier, 2014) and hence more sensitive to these perturbations. It should be noted that ECHAM-HAM does not simulate the effects of nitrate which would be expected to contribute to the ageing of aerosols. 

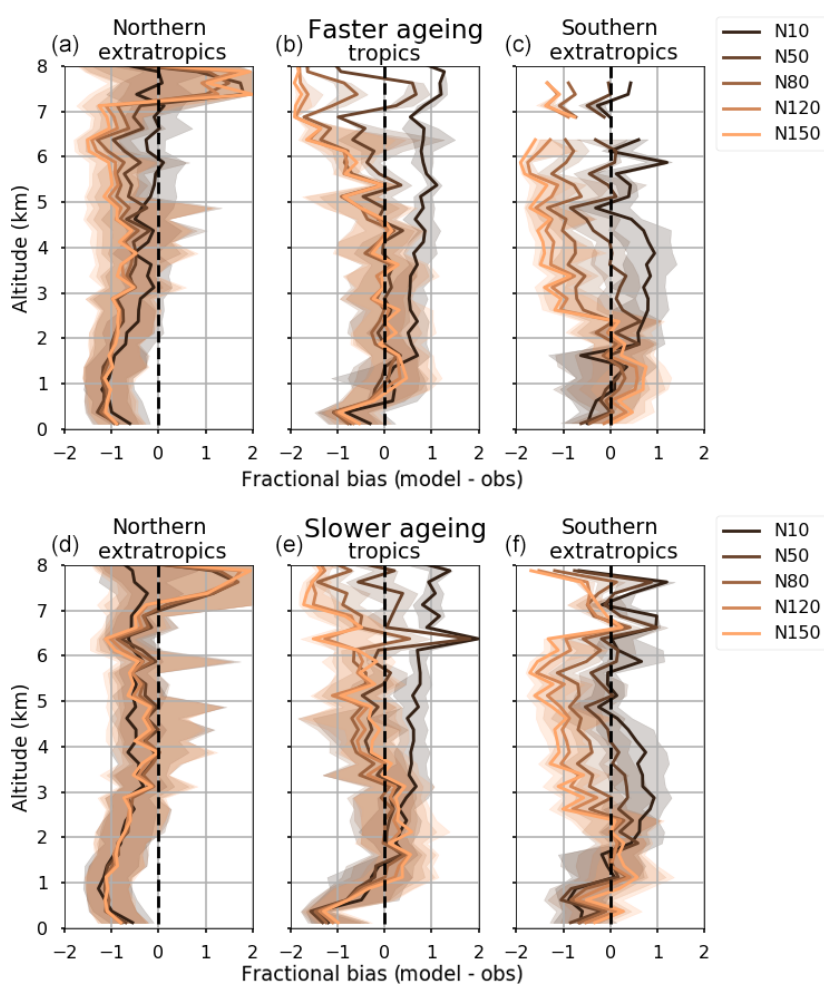

Figure 7. The vertical profile of fractional bias in modelled aerosol number at different size cut-offs for measurements in the northern extratropics (a), the tropics (b) and the southern extratropics (c) with faster ( 0.3 monolayers required) and slower (five monolayers) condensational ageing rates.

\subsubsection{Wet deposition}

Wet deposition is the primary removal mechanism of aerosol (Textor et al., 2006) as well as in ECHAM-HAM (Stier et al., 2005) and as such should have a strong effect on its vertical profile. There are several uncertainties associated with the removal rates, from the raindrop-aerosol collision efficiency (Seinfeld and Pandis, 2016) to the subgrid covariability between precipitation and aerosol (Gryspeerdt et al., 2015). In order to explore the effect of these uncertainties, we scale the in- and below-cloud removal tendencies up and down by a factor of 2. This large perturbation has the effect of changing the BC mean lifetime, for example, from a baseline value of $\sim 7 \mathrm{~d}$ to $\sim 5$ and $\sim 9 \mathrm{~d}$ for increased and decreased removal rates, respectively. Figure 8 shows profiles of fractional bias for increased and decreased wet-deposition removal rates. The importance of wet deposition in controlling the vertical distribution of the aerosol is immediately apparent. While increasing the wet-deposition rates leads to much stronger low biases in all cases, reducing the wet deposition leads to a dramatic improvement. In the southern extratropics, the size bias is virtually eliminated, although some smaller biases do remain. In the tropics, the bias is also reduced, although in the boundary layer the larger aerosol is now overestimated.
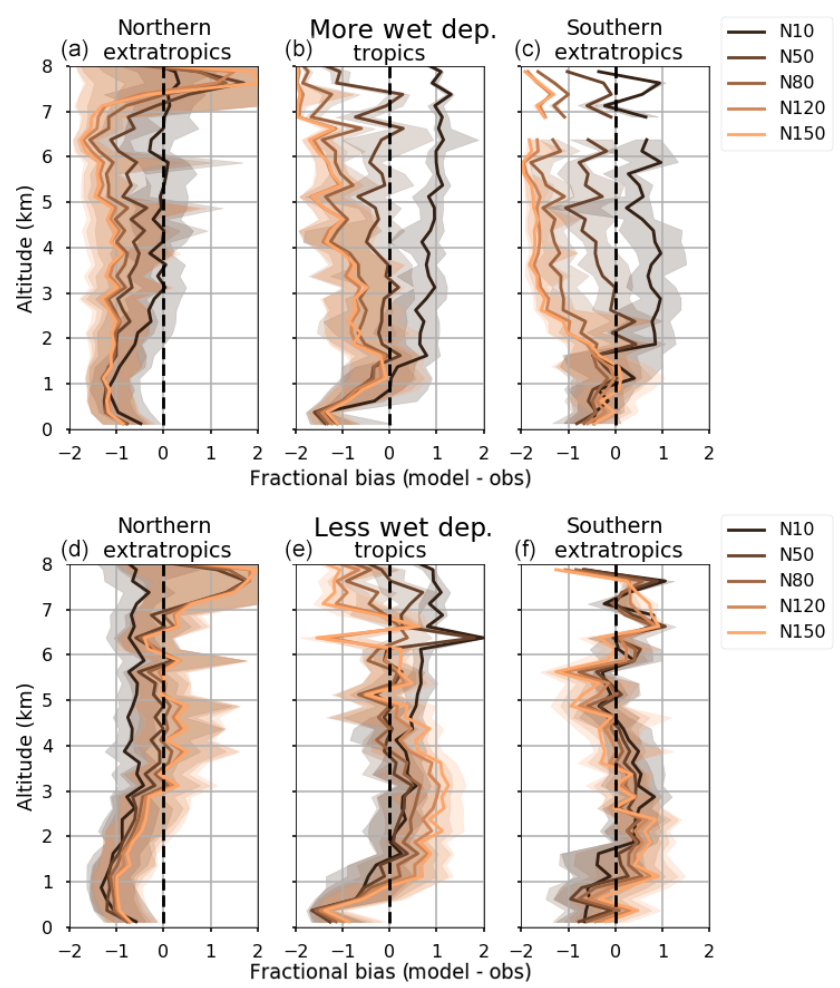

Figure 8. The vertical profile of fractional bias in modelled aerosol number at different size cut-offs for measurements in the northern extratropics (a), the tropics (b) and the southern extratropics (c) with increased (by a factor of 2) and decreased (by a factor of 0.5) wet deposition rates.

The large near-surface bias in the tropics remains unchanged, further suggesting that this bias is due to insufficient sources rather than overefficient removal. In the northern extratropics, the bias in larger particles is virtually eliminated in the free troposphere, at the expense of the smaller particles, however, which now show a low bias, presumably due to the reductions in nucleation through an additional condensational sink. This is suggestive that wet deposition is generally overefficient in HAM but that this is not the only source of the biases shown in Fig. 4c, and that a simple global scaling of the removal rate would be unphysical and probably not be an effective solution. While biases in the precipitation rate could explain some of the aerosol biases, impaction scavenging is a relatively inefficient removal mechanism and ECHAMHAM reproduces global patterns of precipitation reasonably well (e.g. Kipling et al., 2017). Biases in the in-cloud nucleation scavenging, which is a far more efficient mechanism, are therefore the most likely cause.

\subsubsection{Vertical flux in convection}

In order to determine the importance of convection on the vertical distribution of aerosol, we scale the convective tracer entrainment by a factor of 10 up and down. This large pertur- 

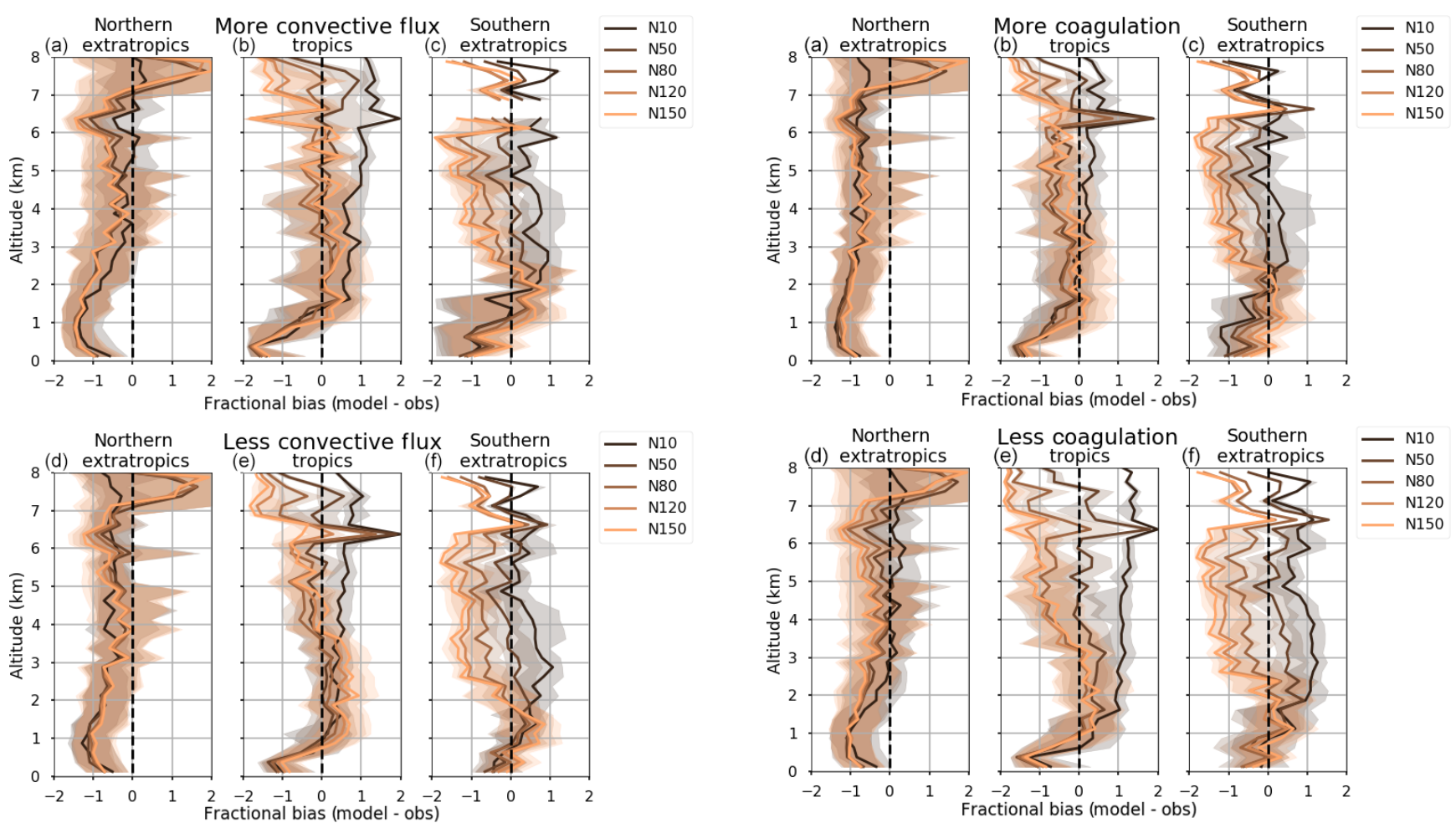

Figure 9. The vertical profile of fractional bias in modelled aerosol number at different size cut-offs for measurements in the northern extratropics (a), the tropics (b) and the southern extratropics (c) with increased (by a factor of 10) and decreased (by a factor of $0.1)$ convective tracer entrainment rates.

bation causes a relatively small response in the vertical number size distribution, as shown in Fig. 9. The largest effect is in the tropics, where reducing the tracer entrainment leads to a reduced bias in the free troposphere for both small and larger particles. The reduced entrainment leads to a positive bias for larger particles in the boundary layer, however. There are also small improvements in the extratropics. Increasing the tracer entrainment leads to increased biases throughout. The reduced entrainment leads to a lower concentration of N10 in the UT, corroborating previous work which showed that the MIT-CAM model had too large a transport of $\mathrm{CN}$ into the upper troposphere (Ekman et al., 2012).

\subsubsection{Coagulation}

Intermode coagulation provides another mechanism by which aerosol can be transferred from insoluble to soluble modes (by coagulating with a particle already in a soluble mode), and intramode coagulation provides a key growth pathway for Aitken- and accumulation-mode aerosol. Both of these will affect the vertical aerosol size distribution, and here we scale both intra- and intermode coagulation by a factor of 2. Figure 10 shows that increasing the coagulation rates reduces the low model bias throughout the troposphere

Figure 10. The vertical profile of fractional bias in modelled aerosol number at different size cut-offs for measurements in the northern extratropics (a), the tropics (b) and the southern extratropics (c) with increased (by a factor of 2.0) and decreased (by a factor of $0.5)$ coagulation rates.

in the tropics and southern extratropics for both larger and smaller particles. The largest improvement is in the tropical free troposphere where coagulation is a dominant mechanism for transfer of number from the nucleation to Aitken and Aitken to accumulation modes, due to the high number densities here (Schutgens and Stier, 2014). Generally, decreasing the coagulation rates increases the model bias, apart from the boundary layer in the northern extratropics where the decrease leads to a small reduction in the bias.

\subsubsection{Dry deposition}

Uncertainty in dry deposition has been shown to provide one of the largest contributions to uncertainty in the surface distribution of CCN in HadGEM-GLOMAP (Lee et al., 2013). However, despite scaling the dry-deposition rates for both the Aitken and accumulation modes over the same ranges, we see no significant change in the distribution of aerosol compared to the aircraft measurements (see Figs. C1-C4). This could be due to the treatment of dry deposition as the lower boundary of the vertical diffusion scheme in ECHAM-HAM (Stier et al., 2005), which minimises spurious surface effects. 

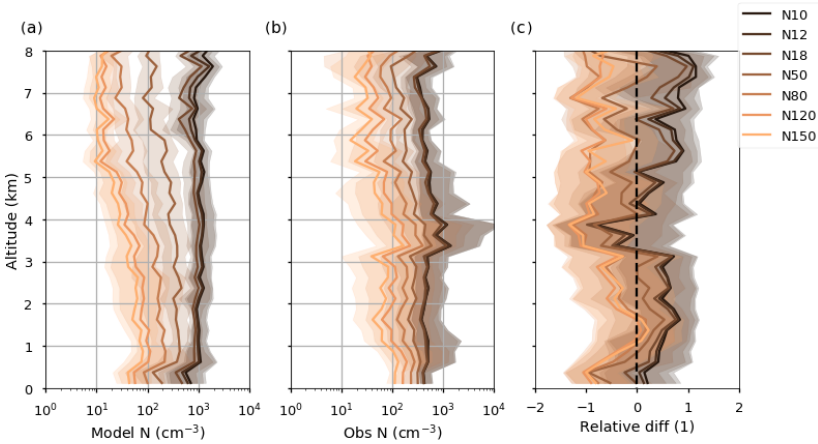

Figure 11. The vertical profile of median fractional bias in model and observed integrated aerosol number at different size cut-offs using SALSA.

\subsection{Comparison with SALSA}

When aerosols grow due to various processes, they can move between modes, e.g. from Aitken to accumulation. Another possible reason for the biases observed in the upper FT is that M7, the default aerosol scheme in ECHAM-HAM, has to perform a redistribution of number between modes, in order to avoid numerical diffusion, often referred to as "mode merging". This can result in "stiff" modes which do not grow or shrink as efficiently as they should. However, the SALSA bin scheme (Kokkola et al., 2008) is also available to use in ECHAM-HAM. Rather than representing the aerosol population as seven log-normal modes as in M7, SALSA uses 20 bins in the standard configuration.

The model aerosol fields are interpolated onto the observational points as with $\mathrm{M} 7$, and the integrated number can be calculated directly by summing the appropriate aerosol bins. The median fractional bias in the integrated number as a function of altitude is shown in Fig. 11. Interestingly, the SALSA aerosol scheme shows a similar negative bias in the large-particle concentration in the upper FT, which suggests the mode merging in M7 is not the cause of the bias in ECHAM-HAM. SALSA also has a small positive bias in smaller particles not present in M7, which may be due to differences in the wet deposition scheme (Bergman et al., 2012). This result suggests that microphysical details can be of secondary importance compared to other physical processes, in particular wet deposition, when it comes to accurately representing the aerosol size distribution. A similar conclusion was reached when investigating the difference between bin and modal schemes in the GLOMAP model (Mann et al., 2012).

\subsection{CCN}

Many of the aircraft included in the NSD analysis above also carried a $\mathrm{CCN}$ counter which is able to measure $\mathrm{CCN}$ either at specific or across a range of supersaturations (see Table 1 for details). By taking all of the measurements at each super-
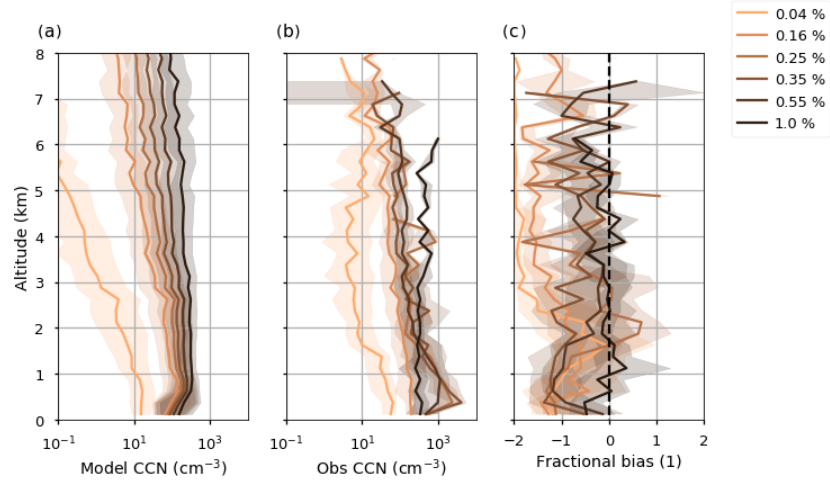

Figure 12. The vertical profile of median collocated model (a), observed (b) and fractional bias (c) in $\mathrm{CCN}$ at the measured supersaturation, as shown in the legend.

saturation and comparing with the model $\mathrm{CCN}$ at the same supersaturation, we are able to create profiles of the fractional bias in $\mathrm{CCN}$ at a range of frequently measured supersaturations, as shown in Fig. 12.

The CCN profiles contain fewer measurements since not all the flights carried a CCNC and some of these instruments "scanned" across supersaturations and hence only measured at any given supersaturation a fraction of the time. As discussed in the introduction, the CCN spectra also depend on both the aerosol size distribution and hygroscopicity, but it can be clearly seen that the bias in the NSD shown in Sect. 4.1 manifests itself in a low bias in the CCN at lower supersaturation (mostly larger particles) in the FT. The same processes identified through the sensitivity analysis as being important for influencing the vertical size distribution, namely wet deposition and condensational growth, control the vertical CCN spectra. Although many cloud regimes are updraft limited rather than CCN limited (Reutter et al., 2009), this low bias in low-supersaturation $\mathrm{CCN}$ is likely to have an important impact on the forcing in those CCN-limited regimes.

\section{Discussion and conclusions}

We have evaluated the vertical size distribution of submicron aerosol particles in the global aerosol model ECHAMHAM using a dataset of in situ aircraft measurements that covers large parts of the globe. The model generally performs well considering the challenges in reproducing in situ observations with a global model but shows a negative bias in accumulation-mode aerosol in the middle to upper troposphere, although due to the exponential decrease in pressure the absolute biases in concentration are still small. By comparing the bias over land and ocean, we show that this bias could result from errors in the ageing and removal processes rather than in the emissions. This bias in particle concentrations translates into a negative bias for low-supersaturation 
$\mathrm{CCN}$ at similar altitudes. The model also underestimates marine sulfate in the boundary layer, likely due to an underrepresentation of DMS emissions. A similar bias, which contributed to an overly large aerosol forcing, has been seen in UKESM1 (Mulcahy et al., 2018) and will be explored in other models in future work.

We also performed a simple one-at-a-time parameter perturbation study (summarised in Fig. B1), which showed that wet deposition, a key aerosol removal process in ECHAMHAM, is probably overefficient, particularly in the southern extratropics. One potential reason for this overefficiency is the assumption (common in GCMs) that aerosol mixes instantaneously across a grid box (Gryspeerdt et al., 2014). Both tracer entrainment and coagulation are shown to be important mechanisms controlling the vertical distribution of aerosol in the tropics but with limited impact elsewhere. The modelled aerosol size distribution shows reduced bias compared to the aircraft measurements when these processes are tuned up and down, respectively. Condensational growth is particularly important in the northern extratropics, where slower ageing (requiring an increased amount of sulfate) reduces the model bias. A similar sensitivity analysis for HadGEM United Kingdom Chemistry and Aerosols model (HadGEM-UKCA; Kipling et al., 2016) showed qualitatively similar results: reduced condensational growth led to fewer small particles and more large particles in the upper troposphere, with coagulation having the greatest effect on particle concentrations in the tropics. In this study, however, ECHAM-HAM does not show the pronounced effect of convective entrainment or dry deposition seen in HadGEMUKCA. This could be due to the different convective parameterisations used in each model and the treatment of dry deposition as a lower boundary of the vertical diffusion scheme in ECHAM-HAM, which minimises spurious surface effects.

These simple perturbations do not allow us to explore the complex interactions between these processes, but they do demonstrate the magnitude of the single effects, and they highlight the value of these measurements in evaluating them. By performing a full sampling of these parameterisations and combining the constraints developed in this work with other remote-sensing datasets, it will be possible to significantly improve our confidence in the representation of aerosol in ECHAM-HAM.
The increasing availability of aircraft datasets measuring the vertical distribution of aerosol, particularly in the UT, provides valuable constraints for GCMs, with implications for improving our representation of aerosol direct and indirect effects in these models.

The single model year used in the present evaluation introduces some uncertainty in the representativeness of the model values when compared with in situ measurements. The sensitivity analyses performed also depend on the particular representation of specific processes used in ECHAMHAM and may behave differently in other GCMs (structural uncertainty). A multi-model, multi-year experiment to apply these constraints within the AeroCom framework and explore intermodel biases and structural uncertainties is currently underway. This will also include measurements from the ATOm (atmospheric tomography) campaign, designed specifically to explore the vertical distribution of aerosol and precursor gases in the remote atmosphere (Wofsy et al., 2018). Further, by combining the number size distribution data used here with speciated mass concentration data from, e.g. AMS measurements, it should be possible to provide detailed insight into any deficiencies in the aerosol life cycle in these models.

Data availability. All model outputs are available from the authors upon request. The GASSP dataset will be publicly released in due course. 


\section{Appendix A}
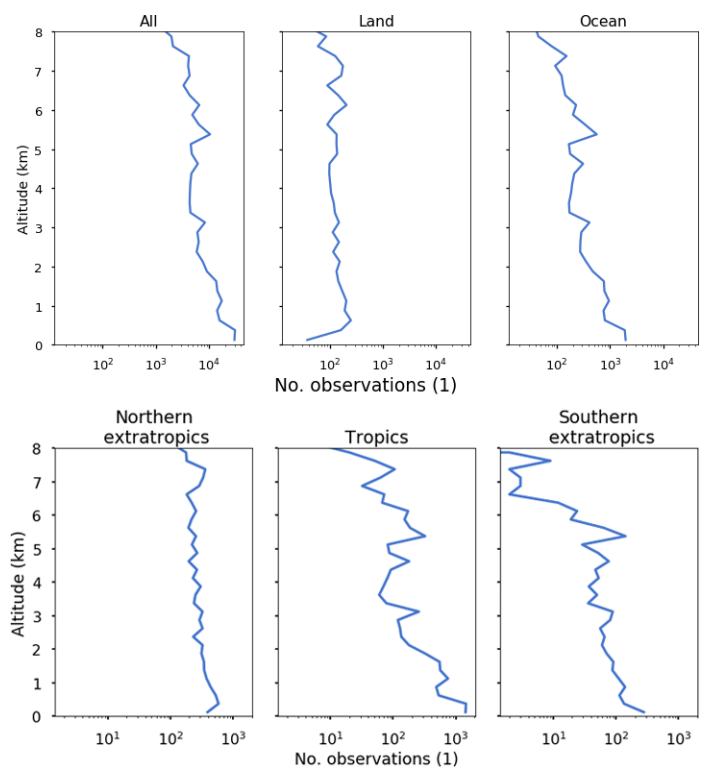

Figure A1. The number of observations (and model points) used in each altitude bin for different subsets of the data used throughout the analysis.

\section{Appendix B}
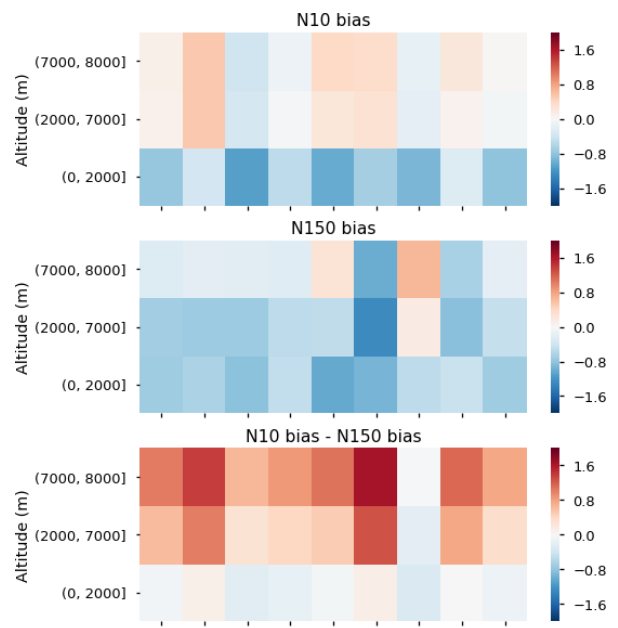

Figure B1. Summaries of the fractional bias (model - obs) in N10 and N150 for each of the sensitivity experiments across three (unequal) altitude ranges. The difference between bias in N10 and N150 is also shown. 


\section{Appendix C}
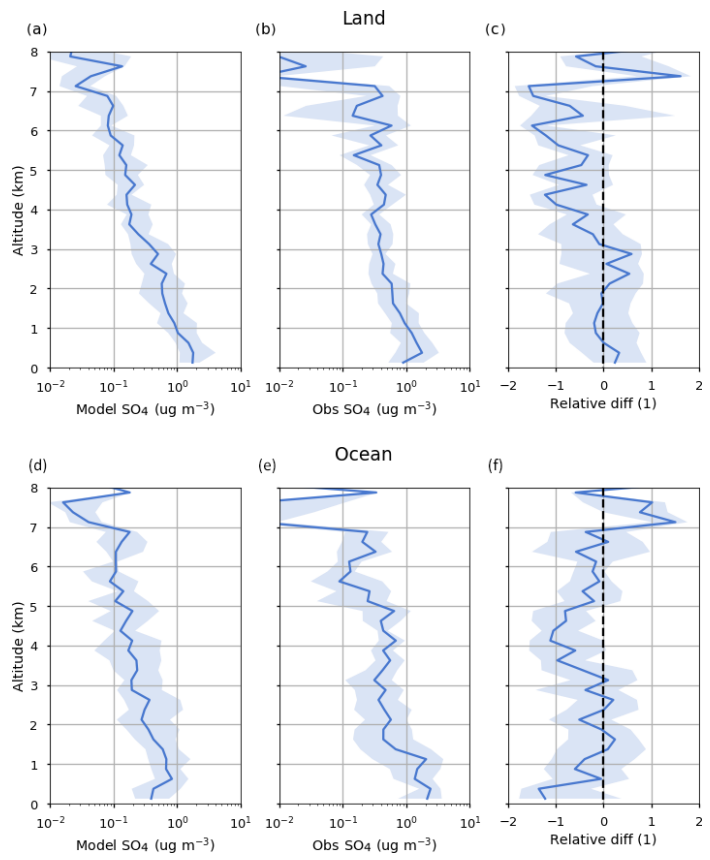

Figure C1. The vertical profiles of modelled (a), observed (b) and fractional bias (c) in $\mathrm{SO}_{4}$ mass concentration for measurements over land and ocean.

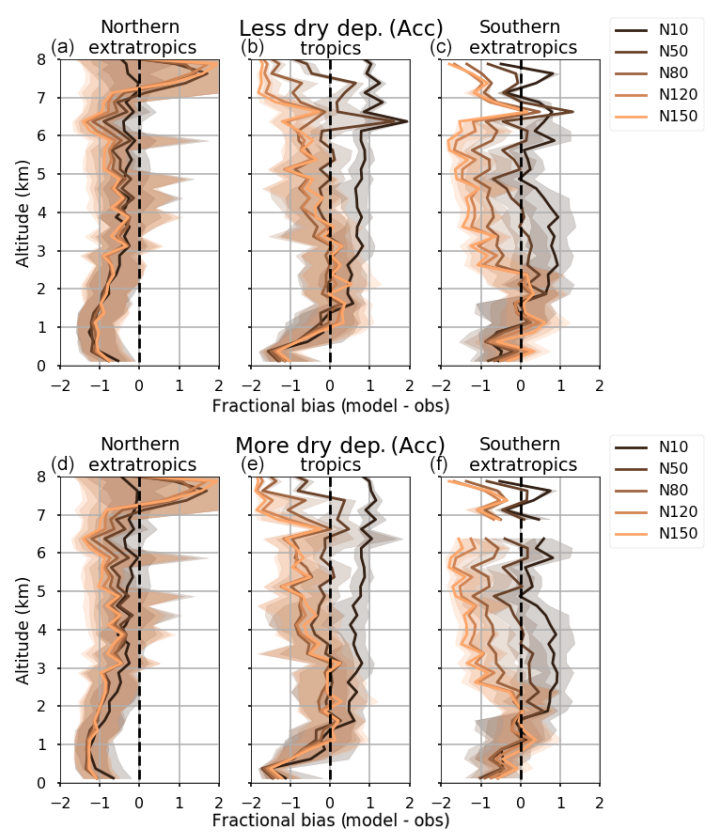

Figure C2. The vertical profile of fractional bias in modelled aerosol number at different size cut-offs for measurements in the northern extratropics (a), the tropics (b) and the southern extratropics (c) with reduced (by a factor of 0.1) and increased (by a factor of 10) dry deposition in the accumulation mode. 

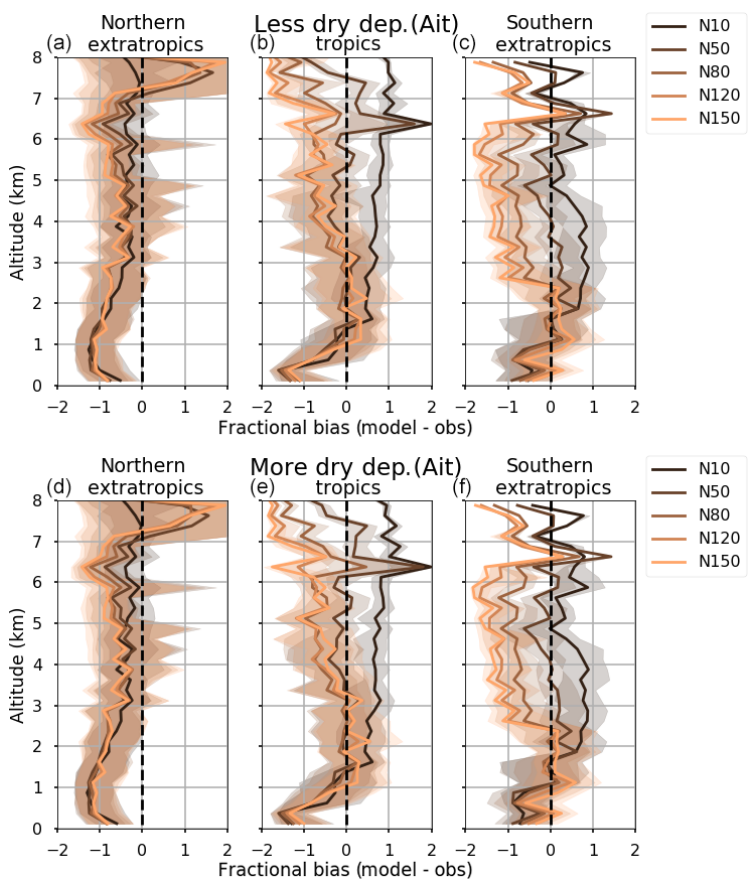

Figure C3. The vertical profile of fractional bias in modelled aerosol number at different size cut-offs for measurements in the northern extratropics (a), the tropics (b) and the southern extratropics (c) with reduced (by a factor of 0.5) and increased (by a factor of 2) dry deposition in the Aitken mode. 

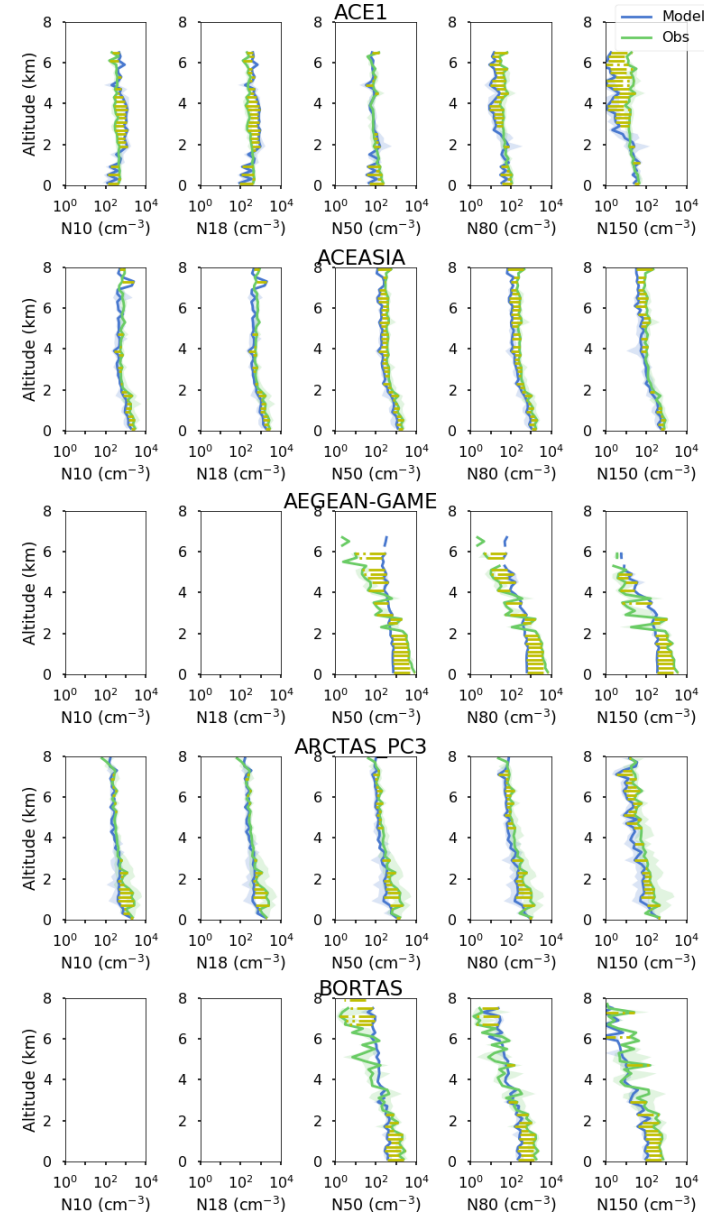

Figure C4.
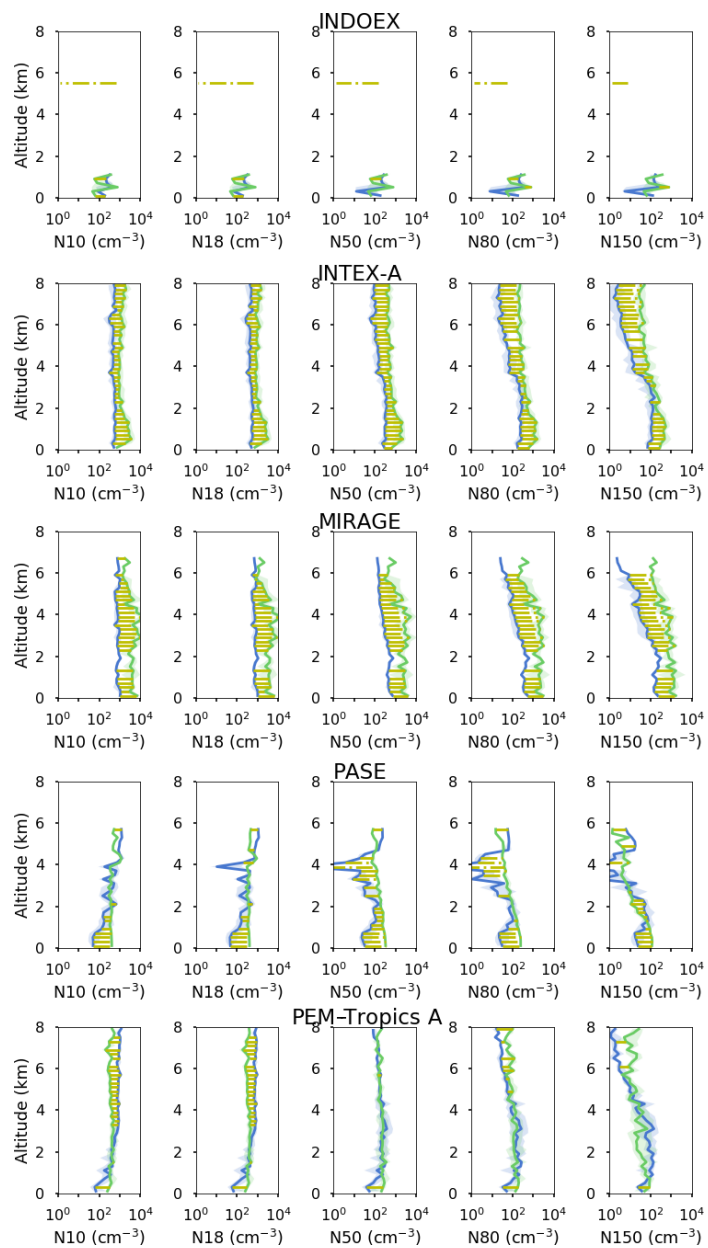

Figure C4. 

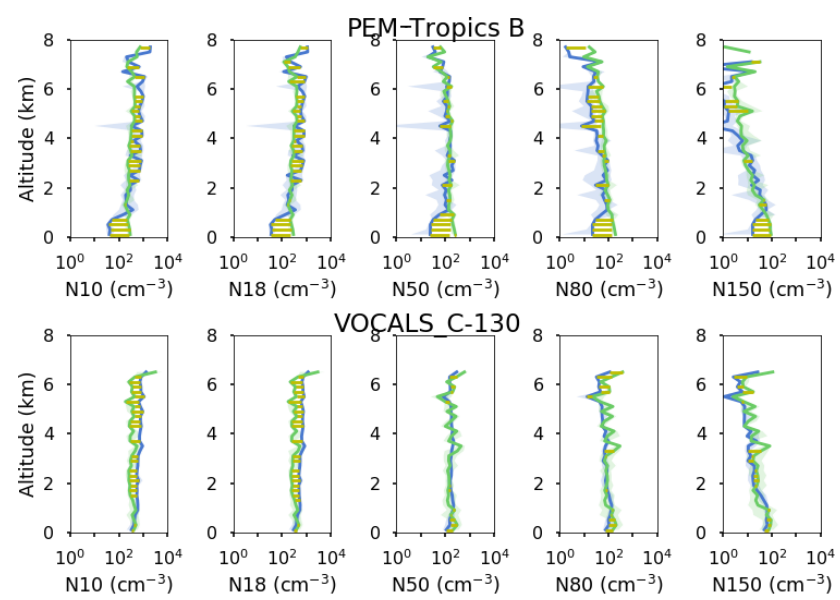

VOC_ALSCC-130 8
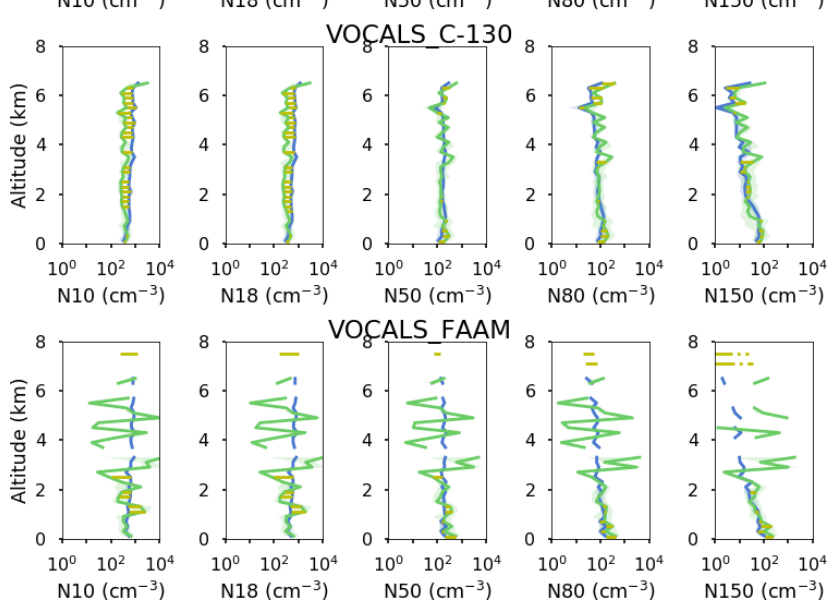

$\mathrm{N} 150\left(\mathrm{~cm}^{-3}\right)$

Figure C4. Per-campaign median profiles of aerosol number at different sizes. Yellow lines indicate a significant difference at that altitude. 
Author contributions. DWP and PS designed the experiments and DWP carried them out. DWP and NS performed the simulations. $\mathrm{CR}, \mathrm{KP}, \mathrm{DL}, \mathrm{JA}, \mathrm{HC}$ and KC provided the formatted and standardised aircraft data. DWP prepared the manuscript with contributions from all co-authors.

Competing interests. The authors declare that they have no conflict of interest.

Acknowledgements. The authors thank Jens Redemann, Jamie Trenbeth, Harri Kokkola and Dan Partridge for useful discussions.

Duncan Watson-Parris and Philip Stier acknowledge funding from Natural Environment Research Council projects NE/J022624/1 (GASSP), NE/L01355X/1 (CLARIFY), NE/M017206/1 (IMPALA) and NE/P013406/1 (A-CURE) and from the Science and Technology Facilities Council project ST/P003206/1 (EVADE). Philip Stier also acknowledges funding from the European Research Council project RECAP under the European Union's Horizon 2020 research and innovation programme with grant agreement 724602 and the European Union's Seventh Framework Programme (FP7/2007-2013) project BACCHUS under grant agreement 603445. Ken S. Carslaw acknowledges funding from the Natural Environment Research Council projects NE/J022624/1 (GASSP), NE/L01355X/1 (CLARIFY) and NE/P013406/1 (A-CURE). The ECHAM-HAMMOZ model is developed by a consortium composed of ETH Zurich, Max Planck Institut für Meteorologie, Forschungszentrum Jülich, University of Oxford, the Finnish Meteorological Institute and the Leibniz Institute for Tropospheric Research, and managed by the Center for Climate Systems Modeling (C2SM) at ETH Zurich. The ECHAM-HAM simulations were performed using the ARCHER UK National Supercomputing Service. FAAM airborne data were obtained using the BAe-146 Atmospheric Research Aircraft, which was operated by Airtask and jointly funded by the UK Natural Environment Research Council (NERC) and the Met Office. We are grateful to the many PIs who contributed their data to GASSP: Thomas Choularton (ACCACIA, COPE); James Hudson (ACE1, INDOEX); Anthony D. Clarke (ACE1, ACEASIA/ACE-Asia, ARCTAS, INDOEX, INTEX-A, MIRAGE, PASE, PEM-Tropics A+B, VOCALS-REx); Hugh Coe (AMMA, AEGEAN-GAME, BORTAS, EUCAARI-LONGREX, OP3, RONOCO, VOCALS-REx); Jamie Trembath (APPRAISE, EM25, EUCAARI-LONGREX, RONOCO, TROMPEX, VOCALSREx); Athanasios Nenes (ARCPAC, ARCTAS, CALNEX, DC3, DISCOVER-AQ, SEAC4RS, TEXAQS-GoMACCS 2006); Ann Middlebrook (ARCPAC, CALNEX, TEXAQS-GoMACCS 2006); Roya Bahreini (ARCPAC, CALNEX, TEXAQS-GoMACCS 2006); Jose-Luis Jimenez (ARCTAS, DC3, INTEX-B, MIRAGE, SEAC4RS); Bruce Anderson (DISCOVER-AQ, INTEX-A); Jennifer M. Comstock (GoAmazon); Fan Mei (GoAmazon); Rodney Weber (INTEX-A); Greg Roberts (INTEX-B, MIRAGE); Steven Howell (PASE, VOCALS-REx); Daniel J. Jacob (PEM-Tropics A); Geraldine M. Gardner (PEM-Tropics A); Martin G. Schultz (PEM-Tropics A); Robert Talbot (PEM-Tropics A, PEM West A); and Jefferson Snider (VOCALS-REx).
Financial support. This research has been supported by the Natural Environment Research Council (grant nos. NE/J022624/1 (GASSP), NE/L01355X/1 (CLARIFY), NE/M017206/1 (IMPALA), and NE/P013406/1 (A-CURE)), the Science and Technology Facilities Council (grant no. ST/P003206/1 (EVADE)), the European Research Council (grant no. RECAP (724602)) and the European Commission (grant no. BACCHUS (603445)).

Review statement. This paper was edited by Alma Hodzic and reviewed by three anonymous referees.

\section{References}

Andrews, S. J., Jones, C. E., and Carpenter, L. J.: Aircraft measurements of very short-lived halocarbons over the tropical Atlantic Ocean, Geophys. Res. Lett., 40, 1005-01010, https://doi.org/10.1002/grl.50141, 2013.

Asa-Awuku, A., Moore, R. H., Nenes, A., Bahreini, R., Holloway, J. S., Brock, C. A., Middlebrook, A. M., Ryerson, T. B., Jimenez, J. L., DeCarlo, P. F., Hecobian, A., Weber, R. J., Stickel, R., Tanner, D. J., and Huey, L. G.: Airborne cloud condensation nuclei measurements during the 2006 Texas Air Quality Study, J. Geophys. Res.-Atmos., (1984-2012), 116, D11201, https://doi.org/10.1029/2010jd014874, 2011.

Barth, M. C., Cantrell, C. A., Brune, W. H., Rutledge, S. A., Crawford, J. H., Huntrieser, H., Carey, L. D., MacGorman, D., Weisman, M., Pickering, K. E., Bruning, E., Anderson, B., Apel, E., Biggerstaff, M., Campos, T., Campuzano-Jost, P., Cohen, R., Crounse, J., Day, D. A., Diskin, G., Flocke, F., Fried, A., Garland, C., Heikes, B., Honomichl, S., Hornbrook, R., Huey, L. G., Jimenez, J. L., Lang, T., Lichtenstern, M., Mikoviny, T., Nault, B., O’Sullivan, D., Pan, L. L., Peischl, J., Pollack, I., Richter, D., Riemer, D., Ryerson, T., Schlager, H., Clair, J. S., Walega, J., Weibring, P., Weinheimer, A., Wennberg, P., Wisthaler, A., Wooldridge, P. J., and Ziegler, C.: The Deep Convective Clouds and Chemistry (DC3) Field Campaign, B. Am. Meteorol. Soc., 96, 12810-1309, https://doi.org/10.1175/bamsd-13-00290.1, 2015.

Bergman, T., Kerminen, V.-M., Korhonen, H., Lehtinen, K. J., Makkonen, R., Arola, A., Mielonen, T., Romakkaniemi, S., Kulmala, M., and Kokkola, H.: Evaluation of the sectional aerosol microphysics module SALSA implementation in ECHAM5HAM aerosol-climate model, Geosci. Model Dev., 5, 845-868, https://doi.org/10.5194/gmd-5-845-2012, 2012.

Berkoff, T. A., Welton, E. J., Campbell, J. R., Valencia, S., Spinhirne, J. D., Tsay, S.-C., and Holben, B. N.: Observations of Aerosols using the Micro-Pulse Lidar NETwork (MPLNET), IGARSS 2004. 2004 IEEE Int. Geosci. Remote Sens. Symp., 3, 2208-2211, https://doi.org/10.1109/igarss.2004.1370799, 2004.

Bezantakos, S., Barmpounis, K., Giamarelou, M., Bossioli, E., Tombrou, M., Mihalopoulos, N., Eleftheriadis, K., Kalogiros, J., D. Allan, J., Bacak, A., Percival, C. J., Coe, H., and Biskos, G.: Chemical composition and hygroscopic properties of aerosol particles over the Aegean Sea, Atmos. Chem. Phys., 13, 11595 11608, https://doi.org/10.5194/acp-13-11595-2013, 2013.

Brock, C. A., Cozic, J., Bahreini, R., Froyd, K. D., Middlebrook, A. M., McComiskey, A., Brioude, J., Cooper, O. R., Stohl, A., 
Aikin, K. C., de Gouw, J. A., Fahey, D. W., Ferrare, R. A., Gao, R.-S., Gore, W., Holloway, J. S., Hübler, G., Jefferson, A., Lack, D. A., Lance, S., Moore, R. H., Murphy, D. M., Nenes, A., Novelli, P. C., Nowak, J. B., Ogren, J. A., Peischl, J., Pierce, R. B., Pilewskie, P., Quinn, P. K., Ryerson, T. B., Schmidt, K. S., Schwarz, J. P., Sodemann, H., Spackman, J. R., Stark, H., Thomson, D. S., Thornberry, T., Veres, P., Watts, L. A., Warneke, C., and Wollny, A. G.: Characteristics, sources, and transport of aerosols measured in spring 2008 during the aerosol, radiation, and cloud processes affecting Arctic Climate (ARCPAC) Project, Atmos. Chem. Phys., 11, 24232453, https://doi.org/10.5194/acp-11-2423-2011, 2011.

Canagaratna, M. R., Jayne, J. T., Jimenez, J. L., Allan, J. D., Alfarra, M. R., Zhang, Q., Onasch, T. B., Drewnick, F., Coe, H., Middlebrook, A., Delia, A., Williams, L. R., Trimborn, A. M., Northway, M. J., DeCarlo, P. F., Kolb, C. E., Davidovits, P., and Worsnop, D. R.: Chemical and microphysical characterization of ambient aerosols with the aerodyne aerosol mass spectrometer, Mass Spectrom. Rev., 26, 185-222, https://doi.org/10.1002/mas.20115, 2007.

Clarke, A. D.: A thermo-optic technique for in situ analysis of sizeresolved aerosol physicochemistry, Atmos. Environ. Part A, 25, 635-644, https://doi.org/10.1016/0960-1686(91)90061-B, 1991.

Clarke, A. D. and Kapustin, V. N.: A Pacific Aerosol Survey. Part I: A Decade of Data on Particle Production, Transport, Evolution, and Mixing in the Troposphere*, J. Atmos. Sci., 59, 363-382, https://doi.org/10.1175/15200469(2002)059<0363:apaspi>2.0.co;2, 2002.

Clarke, A. D., Varner, J. L., Eisele, F., Mauldin, R. L., Tanner, D., and Litchy, M.: Particle production in the remote marine atmosphere: Cloud outflow and subsidence during ACE 1, J. Geophys. Res.-Atmos., 103, 16397-16409, https://doi.org/10.1029/97jd02987, 1998.

Clarke, A., Collins, W. G., Rasch, P. J., Kapustin, V. N., Moore, K., Howell, S., and Fuelberg, H. E.: Dust and pollution transport on global scales: Aerosol measurements and model predictions, J. Geophys. Res.-Atmos., 106, 32555-32569, https://doi.org/10.1029/2000JD900842, 2001.

Clarke, A., Howell, S., Quinn, P. K., Bates, T. S., Ogren, J. A., Andrews, E., Jefferson, A., Massling, A., Bracero, O. M., Maring, H., Savoie, D., and Cass, G.: INDOEX aerosol: A comparison and summary of chemical, microphysical, and optical properties observed from land, ship, and aircraft, J. Geophys. Res.-Atmos., 107, INX2 32-1-INX2 32-32, https://doi.org/10.1029/2001JD000572, 2002.

Clarke, A., McNaughton, C., Kapustin, V., Shinozuka, Y., Howell, S., Dibb, J., Zhou, J., Anderson, B., Brekhovskikh, V., Turner, H., and Pinkerton, M.: Biomass burning and pollution aerosol over North America: Organic components and their influence on spectral optical properties and humidification response, J. Geophys. Res., 112, D12S18, https://doi.org/10.1029/2006JD007777, 2007.

Clarke, A. D., Freitag, S., Simpson, R. M. C., Hudson, J. G., Howell, S. G., Brekhovskikh, V. L., Campos, T., Kapustin, V. N., and Zhou, J.: Free troposphere as a major source of $\mathrm{CCN}$ for the equatorial pacific boundary layer: long-range transport and teleconnections, Atmos. Chem. Phys., 13, 7511-7529, https://doi.org/10.5194/acp-13-7511-2013, 2013.
Croft, B., Lohmann, U., Martin, R. V., Stier, P., Wurzler, S., Feichter, J., Posselt, R., and Ferrachat, S.: Aerosol sizedependent below-cloud scavenging by rain and snow in the ECHAM5-HAM, Atmos. Chem. Phys., 9, 4653-4675, https://doi.org/10.5194/acp-9-4653-2009, 2009.

Croft, B., Lohmann, U., Martin, R. V., Stier, P., Wurzler, S., Feichter, J., Hoose, C., Heikkilä, U., van Donkelaar, A., and Ferrachat, S.: Influences of in-cloud aerosol scavenging parameterizations on aerosol concentrations and wet deposition in ECHAM5-HAM, Atmos. Chem. Phys., 10, 1511-1543, https://doi.org/10.5194/acp-10-1511-2010, 2010.

Crosier, J., Bower, K. N., Choularton, T. W., Westbrook, C. D., Connolly, P. J., Cui, Z. Q., Crawford, I. P., Capes, G. L., Coe, H., Dorsey, J. R., Williams, P. I., Illingworth, A. J., Gallagher, M. W., and Blyth, A. M.: Observations of ice multiplication in a weakly convective cell embedded in supercooled mid-level stratus, Atmos. Chem. Phys., 11, 257-273, https://doi.org/10.5194/acp-11257-2011, 2011.

DeCarlo, P. F., Kimmel, J. R., Trimborn, A., Northway, M. J., Jayne, J. T., Aiken, A. C., Gonin, M., Fuhrer, K., Horvath, T., Docherty, K. S., Worsnop, D. R., and Jimenez, J. L.: Field-Deployable, High-Resolution, Time-ofFlight Aerosol Mass Spectrometer, Anal. Chem., 78, 8281-8289, https://doi.org/10.1021/ac061249n, 2006.

DeCarlo, P. F., Dunlea, E. J., Kimmel, J. R., Aiken, A. C., Sueper, D., Crounse, J., Wennberg, P. O., Emmons, L., Shinozuka, Y., Clarke, A., Zhou, J., Tomlinson, J., Collins, D. R., Knapp, D., Weinheimer, A. J., Montzka, D. D., Campos, T., and Jimenez, J. L.: Fast airborne aerosol size and chemistry measurements above Mexico City and Central Mexico during the MILAGRO campaign, Atmos. Chem. Phys., 8, 4027-4048, https://doi.org/10.5194/acp-8-4027-2008, 2008.

Dee, D. P., Uppala, S. M., Simmons, A. J., Berrisford, P., Poli, P., Kobayashi, S., Andrae, U., Balmaseda, M. A., Balsamo, G., Bauer, P., Bechtold, P., Beljaars, A. C. M., Berg, L. v. d., Bidlot, J., Bormann, N., Delsol, C., Dragani, R., Fuentes, M., Geer, A. J., Haimberger, L., Healy, S. B., Hersbach, H., Hólm, E. V., Isaksen, L., Kållberg, P., Köhler, M., Matricardi, M., McNally, A. P., Monge-Sanz, B. M., Morcrette, J. J., Park, B. K., Peubey, C., Rosnay, P. d., Tavolato, C., Thépaut, J. N., and Vitart, F.: The ERA-Interim reanalysis: configuration and performance of the data assimilation system, Q. J. Roy. Meteorol. Soc., 137, 553597, https://doi.org/10.1002/qj.828, 2011.

Drewnick, F., Hings, S. S., DeCarlo, P., Jayne, J. T., Gonin, M., Fuhrer, K., Weimer, S., Jimenez, J. L., Demerjian, K. L., Borrmann, S., and Worsnop, D. R.: A new time-of-flight aerosol mass spectrometer (TOF-AMS) - Instrument description and first field deployment, Aerosol Sci. Tech., 39, 637-658, https://doi.org/10.1080/02786820500182040, 2005.

Dunne, E. M., Gordon, H., Kürten, A., Almeida, J., Duplissy, J., Williamson, C., Ortega, I. K., Pringle, K. J., Adamov, A., Baltensperger, U., Barmet, P., Benduhn, F., Bianchi, F., Breitenlechner, M., Clarke, A., Curtius, J., Dommen, J., Donahue, N. M., Ehrhart, S., Flagan, R. C., Franchin, A., Guida, R., Hakala, J., Hansel, A., Heinritzi, M., Jokinen, T., Kangasluoma, J., Kirkby, J., Kulmala, M., Kupc, A., Lawler, M. J., Lehtipalo, K., Makhmutov, V., Mann, G., Mathot, S., Merikanto, J., Miettinen, P., Nenes, A., Onnela, A., Rap, A., Reddington, C. L. S., Riccobono, F., Richards, N. A. D., Rissanen, M. P., 
Rondo, L., Sarnela, N., Schobesberger, S., Sengupta, K., Simon, M., Sipilä, M., Smith, J. N., Stozkhov, Y., Tomé, A., Tröstl, J., Wagner, P. E., Wimmer, D., Winkler, P. M., Worsnop, D. R., and Carslaw, K. S.: Global atmospheric particle formation from CERN CLOUD measurements, Science, 354, 1119-1124, https://doi.org/10.1126/science.aaf2649, 2016.

Ekman, A. M. L., Hermann, M., Groß, P., Heintzenberg, J., Kim, D., and Wang, C.: Sub-micrometer aerosol particles in the upper troposphere/lowermost stratosphere as measured by CARIBIC and modeled using the MIT-CAM3 global climate model, J. Geophys. Res., 117, D11202, https://doi.org/10.1029/2011jd016777, 2012.

Fast, J. D., Berg, L. K., Zhang, K., Easter, R. C., Ferrare, R. A., Hair, J. W., Hostetler, C. A., Liu, Y., Ortega, I., Sedlacek, A., Shilling, J. E., Shrivastava, M., Springston, S. R., Tomlinson, J. M., Volkamer, R., Wilson, J., Zaveri, R. A., and Zelenyuk, A.: Model representations of aerosol layers transported from North America over the Atlantic Ocean during the TwoColumn Aerosol Project, J. Geophys. Res.-Atmos., 121, 98149848, https://doi.org/10.1002/2016jd025248, 2016.

Ganguly, D., Ginoux, P., Ramaswamy, V., Dubovik, O., Welton, J., Reid, E. A., and Holben, B. N.: Inferring the composition and concentration of aerosols by combining AERONET and MPLNET data: Comparison with other measurements and utilization to evaluate GCM output, J. Geophys. Res.-Atmos. (1984-2012), 114, D16203, https://doi.org/10.1029/2009jd011895, 2009.

Gryspeerdt, E., Stier, P., and Partridge, D. G.: Links between satellite-retrieved aerosol and precipitation, Atmos. Chem. Phys., 14, 9677-9694, https://doi.org/10.5194/acp-149677-2014, 2014.

Gryspeerdt, E., Stier, P., White, B. A., and Kipling, Z.: Wet scavenging limits the detection of aerosol effects on precipitation, Atmos. Chem. Phys., 15, 7557-7570, https://doi.org/10.5194/acp15-7557-2015, 2015.

Hamburger, T., McMeeking, G., Minikin, A., Birmili, W., Dall'Osto, M., O'Dowd, C., Flentje, H., Henzing, B., Junninen, H., Kristensson, A., de Leeuw, G., Stohl, A., Burkhart, J. F., Coe, H., Krejci, R., and Petzold, A.: Overview of the synoptic and pollution situation over Europe during the EUCAARILONGREX field campaign, Atmos. Chem. Phys., 11, 10651082, https://doi.org/10.5194/acp-11-1065-2011, 2011.

Heald, C. L., Coe, H., Jimenez, J. L., Weber, R. J., Bahreini, R., Middlebrook, A. M., Russell, L. M., Jolleys, M., Fu, T.-M., Allan, J. D., Bower, K. N., Capes, G., Crosier, J., Morgan, W. T., Robinson, N. H., Williams, P. I., Cubison, M. J., DeCarlo, P. F., and Dunlea, E. J.: Exploring the vertical profile of atmospheric organic aerosol: comparing 17 aircraft field campaigns with a global model, Atmos. Chem. Phys., 11, 12673-12696, https://doi.org/10.5194/acp-11-12673-2011, 2011.

Heikenfeld, M., White, B., Labbouz, L., and Stier, P.: Aerosol effects on deep convection: the propagation of aerosol perturbations through convective cloud microphysics, Atmos. Chem. Phys., 19, 2601-2627, https://doi.org/10.5194/acp-192601-2019, 2019.

Hodzic, A., Madronich, S., Kasibhatla, P. S., Tyndall, G., Aumont, B., Jimenez, J. L., Lee-Taylor, J., and Orlando, J.: Organic photolysis reactions in tropospheric aerosols: effect on secondary or- ganic aerosol formation and lifetime, Atmos. Chem. Phys., 15, 9253-9269, https://doi.org/10.5194/acp-15-9253-2015, 2015.

Hoell, J. M., Davis, D. D., Jacob, D. J., Rodgers, M. O., Newell, R. E., Fuelberg, H. E., McNeal, R. J., Raper, J. L., and Bendura, R. J.: Pacific Exploratory Mission in the tropical Pacific: PEMTropics A, August-September 1996, J. Geophys. Res.-Atmos. 104, 5567-5583, https://doi.org/10.1029/1998JD100074, 1999.

Hoose, C., Lohmann, U., Stier, P., Verheggen, B., and Weingartner, E.: Aerosol processing in mixed-phase clouds in ECHAM5-HAM: Model description and comparison to observations, J. Geophys. Res., 113, D07210, https://doi.org/10.1029/2007JD009251, 2008

Howell, S. G., Clarke, A., Shinozuka, Y., Kapustin, V., McNaughton, C. S., Huebert, B. J., Doherty, S. J., and Anderson, T. L.: Influence of relative humidity upon pollution and dust during ACE-Asia: Size distributions and implications for optical properties, J. Geophys. Res., 111, D06205, https://doi.org/10.1029/2004JD005759, 2006.

Hudson, J. G.: An Instantaneous CCN Spectrometer, J. Atmos. Ocean. Technol., 6, 1055-1065, https://doi.org/10.1175/15200426(1989)006<1055:AICS>2.0.CO;2, 1989.

Jacob, D. J., Crawford, J. H., Maring, H., Clarke, A. D., Dibb, J. E., Emmons, L. K., Ferrare, R. A., Hostetler, C. A., Russell, P. B., Singh, H. B., Thompson, A. M., Shaw, G. E., McCauley, E., Pederson, J. R., and Fisher, J. A.: The Arctic Research of the Composition of the Troposphere from Aircraft and Satellites (ARCTAS) mission: design, execution, and first results, Atmos. Chem. Phys., 10, 5191-5212, https://doi.org/10.5194/acp10-5191-2010, 2010.

Kacenelenbogen, M., Vaughan, M. A., Redemann, J., Hoff, R. M., Rogers, R. R., Ferrare, R. A., Russell, P. B., Hostetler, C. A., Hair, J. W., and Holben, B. N.: An accuracy assessment of the CALIOP/CALIPSO version 2/version 3 daytime aerosol extinction product based on a detailed multi-sensor, multi-platform case study, Atmos. Chem. Phys., 11, 3981-4000, https://doi.org/10.5194/acp-11-3981-2011, 2011.

Kipling, Z., Stier, P., Schwarz, J. P., Perring, A. E., Spackman, J. R., Mann, G. W., Johnson, C. E., and Telford, P. J.: Constraints on aerosol processes in climate models from vertically-resolved aircraft observations of black carbon, Atmos. Chem. Phys., 13, 5969-5986, https://doi.org/10.5194/acp-13-5969-2013, 2013.

Kipling, Z., Stier, P., Johnson, C. E., Mann, G. W., Bellouin, N., Bauer, S. E., Bergman, T., Chin, M., Diehl, T., Ghan, S. J., Iversen, T., Kirkevåg, A., Kokkola, H., Liu, X., Luo, G., van Noije, T., Pringle, K. J., von Salzen, K., Schulz, M., Seland, Ø., Skeie, R. B., Takemura, T., Tsigaridis, K., and Zhang, K.: What controls the vertical distribution of aerosol? Relationships between process sensitivity in HadGEM3-UKCA and inter-model variation from AeroCom Phase II, Atmos. Chem. Phys., 16, 2221-2241, https://doi.org/10.5194/acp-16-2221-2016, 2016.

Kipling, Z., Stier, P., Labbouz, L., and Wagner, T.: Dynamic subgrid heterogeneity of convective cloud in a global model: description and evaluation of the Convective Cloud Field Model (CCFM) in ECHAM6-HAM2, Atmos. Chem. Phys., 17, 327 342, https://doi.org/10.5194/acp-17-327-2017, 2017.

Knutson, E. O. and Whitby, K. T.: Aerosol classification by electric mobility: Apparatus, theory, and application, J. Aerosol. Sci., 6, 443-451, https://doi.org/10.1016/0021-8502(75)90060-9, 1975. 
Koch, D., Schulz, M., Kinne, S., McNaughton, C., Spackman, J. R., Balkanski, Y., Bauer, S., Berntsen, T., Bond, T. C., Boucher, O., Chin, M., Clarke, A., De Luca, N., Dentener, F., Diehl, T., Dubovik, O., Easter, R., Fahey, D. W., Feichter, J., Fillmore, D., Freitag, S., Ghan, S., Ginoux, P., Gong, S., Horowitz, L., Iversen, T., Kirkevåg, A., Klimont, Z., Kondo, Y., Krol, M., Liu, X., Miller, R., Montanaro, V., Moteki, N., Myhre, G., Penner, J. E., Perlwitz, J., Pitari, G., Reddy, S., Sahu, L., Sakamoto, H., Schuster, G., Schwarz, J. P., Seland, Ø., Stier, P., Takegawa, N., Takemura, T., Textor, C., van Aardenne, J. A., and Zhao, Y.: Evaluation of black carbon estimations in global aerosol models, Atmos. Chem. Phys., 9, 9001-9026, https://doi.org/10.5194/acp-99001-2009, 2009.

Koffi, B., Schulz, M., Bréon, F. M., Griesfeller, J., Winker, D., Balkanski, Y., Bauer, S., Berntsen, T., Chin, M., Collins, W. D., Dentener, F., Diehl, T., Easter, R., Ghan, S., Ginoux, P., Gong, S., Horowitz, L. W., Iversen, T., Kirkevåg, A., Koch, D., Krol, M., Myhre, G., Stier, P., and Takemura, T.: Application of the CALIOP layer product to evaluate the vertical distribution of aerosols estimated by global models: AeroCom phase I results, J. Geophys. Res., 117, D10201, https://doi.org/10.1029/2011jd016858, 2012.

Koffi, B., Schulz, M., Bréon, F. M., Dentener, F., Steensen, B. M., Griesfeller, J., Winker, D., Balkanski, Y., Bauer, S. E., Bellouin, N., Berntsen, T., Bian, H., Chin, M., Diehl, T., Easter, R., Ghan, S., Hauglustaine, D. A., Iversen, T., Kirkevåg, A., Liu, X., Lohmann, U., Myhre, G., Rasch, P., Seland, Ø., Skeie, R. B., Steenrod, S. D., Stier, P., Tackett, J., Takemura, T., Tsigaridis, K., Vuolo, M. R., Yoon, J., and Zhang, K.: Evaluation of the aerosol vertical distribution in global aerosol models through comparison against CALIOP measurements: AeroCom phase II results, J. Geophys. Res.-Atmos., 121, 7254-7283, https://doi.org/10.1002/2015jd024639, 2016.

Kokkola, H., Korhonen, H., Lehtinen, K. E. J., Makkonen, R., Asmi, A., Järvenoja, S., Anttila, T., Partanen, A.-I., Kulmala, M., Järvinen, H., Laaksonen, A., and Kerminen, V.-M.: SALSA - a Sectional Aerosol module for Large Scale Applications, Atmos. Chem. Phys., 8, 2469-2483, https://doi.org/10.5194/acp-8-24692008, 2008.

Lamarque, J.-F., Bond, T. C., Eyring, V., Granier, C., Heil, A., Klimont, Z., Lee, D., Liousse, C., Mieville, A., Owen, B., Schultz, M. G., Shindell, D., Smith, S. J., Stehfest, E., Van Aardenne, J., Cooper, O. R., Kainuma, M., Mahowald, N., McConnell, J. R., Naik, V., Riahi, K., and van Vuuren, D. P.: Historical (1850-2000) gridded anthropogenic and biomass burning emissions of reactive gases and aerosols: methodology and application, Atmos. Chem. Phys., 10, 7017-7039, https://doi.org/10.5194/acp-10-7017-2010, 2010.

Lance, S., Nenes, A., Medina, J., and Smith, J. N.: Mapping the Operation of the DMT Continuous Flow CCN Counter, Aerosol Sci. Technol., 40, 242-254, https://doi.org/10.1080/02786820500543290, 2006.

Lee, L. A., Pringle, K. J., Reddington, C. L., Mann, G. W., Stier, P., Spracklen, D. V., Pierce, J. R., and Carslaw, K. S.: The magnitude and causes of uncertainty in global model simulations of cloud condensation nuclei, Atmos. Chem. Phys., 13, 8879-8914, https://doi.org/10.5194/acp-13-8879-2013, 2013.

Leon, D. C., French, J. R., Lasher-Trapp, S., Blyth, A. M., Abel, S. J., Ballard, S., Barrett, A., Bennett, L. J., Bower, K., Brooks,
B., Brown, P., Charlton-Perez, C., Choularton, T., Clark, P., Collier, C., Crosier, J., Cui, Z., Dey, S., Dufton, D., Eagle, C., Flynn, M. J., Gallagher, M., Halliwell, C., Hanley, K., Hawkness-Smith, L., Huang, Y., Kelly, G., Kitchen, M., Korolev, A., Lean, H., Liu, Z., Marsham, J., Moser, D., Nicol, J., Norton, E. G., Plummer, D., Price, J., Ricketts, H., Roberts, N., Rosenberg, P. D., Simonin, D., Taylor, J. W., Warren, R., Williams, P. I., Young, G., Leon, D. C., French, J. R., Lasher-Trapp, S., Ballard, S., Barrett, A., Bennett, L. J., Bower, K., Brooks, B., Brown, P., CharltonPerez, C., Choularton, T., Clark, P., Collier, C., Cui, Z., Dey, S., Dufton, D., Eagle, C., Gallagher, M., Halliwell, C., Hanley, K., Hawkness-Smith, L., Huang, Y., Kelly, G., Kitchen, M., Korolev, A., Lean, H., Marsham, J., Moser, D., Nicol, J., Norton, E. G., Plummer, D., Price, J., Ricketts, H., Roberts, N., Rosenberg, P. D., Simonin, D., and Warren, R.: The Convective Precipitation Experiment (COPE): Investigating the Origins of Heavy Precipitation in the Southwestern United Kingdom, B. Am. Meteorol. Soc., 97, 1003-1020, https://doi.org/10.1175/BAMS-D14-00157.1, 2016.

Leppä, J., Mui, W., Grantz, A. M., and Flagan, R. C.: Charge distribution uncertainty in differential mobility analysis of aerosols, Aerosol Sci. Technol., 51, 1168-1189, https://doi.org/10.1080/02786826.2017.1341039, 2017.

Li, J., Carlson, B. E., and Lacis, A. A.: Application of spectral analysis techniques in the intercomparison of aerosol data: 1 . An EOF approach to analyze the spatial-temporal variability of aerosol optical depth using multiple remote sensing data sets, J. Geophys. Res.-Atmos., 118, 8640-8648, 2013.

Lin, S. and Rood, R.: Multidimensional Flux-Form Semi-Lagrangian Transport Schemes, Mon. Weather Rev., 124, 2046-2070, https://doi.org/10.1175/15200493(1996)124<2046:MFFSLT>2.0.CO;2, 1996.

Liu, B. Y. H. and Pui, D. Y. H.: Electrical Neutralization of Aerosols, J. Aerosol. Sci., 5, 465-472, https://doi.org/10.1016/0021-8502(74)90086-X, 1974.

Lloyd, G., Choularton, T. W., Bower, K. N., Crosier, J., Jones, H., Dorsey, J. R., Gallagher, M. W., Connolly, P., Kirchgaessner, A. C. R., and Lachlan-Cope, T.: Observations and comparisons of cloud microphysical properties in spring and summertime Arctic stratocumulus clouds during the ACCACIA campaign, Atmos. Chem. Phys., 15, 3719-3737, https://doi.org/10.5194/acp15-3719-2015, 2015.

Lohmann, U. and Hoose, C.: Sensitivity studies of different aerosol indirect effects in mixed-phase clouds, Atmos. Chem. Phys., 9, 8917-8934, https://doi.org/10.5194/acp-9-8917-2009, 2009.

Lohmann, U. and Neubauer, D.: The importance of mixed-phase and ice clouds for climate sensitivity in the global aerosolclimate model ECHAM6-HAM2, Atmos. Chem. Phys., 18, 8807-8828, https://doi.org/10.5194/acp-18-8807-2018, 2018.

Lohmann, U., Stier, P., Hoose, C., Ferrachat, S., Kloster, S., Roeckner, E., and Zhang, J.: Cloud microphysics and aerosol indirect effects in the global climate model ECHAM5-HAM, Atmos. Chem. Phys., 7, 3425-3446, https://doi.org/10.5194/acp-7-34252007, 2007.

López-Yglesias, X. and Flagan, R. C.: Ion-Aerosol Flux Coefficients and the Steady-State Charge Distribution of Aerosols in a Bipolar Ion Environment, Aerosol Sci. Technol., 47, 688-704, 10.1080/02786826.2013.783684, 2013. 
Mahmood, R., von Salzen, K., Flanner, M., Sand, M., Langner, J., Wang, H., and Huang, L.: Seasonality of global and Arctic black carbon processes in the Arctic Monitoring and Assessment Programme models, J. Geophys. Res.-Atmos., 121, 7100-7116, https://doi.org/10.1002/2016JD024849, 2016.

Mann, G. W., Carslaw, K. S., Ridley, D. A., Spracklen, D. V., Pringle, K. J., Merikanto, J., Korhonen, H., Schwarz, J. P., Lee, L. A., Manktelow, P. T., Woodhouse, M. T., Schmidt, A., Breider, T. J., Emmerson, K. M., Reddington, C. L., Chipperfield, M. P., and Pickering, S. J.: Intercomparison of modal and sectional aerosol microphysics representations within the same 3-D global chemical transport model, Atmos. Chem. Phys., 12, 4449-4476, https://doi.org/10.5194/acp-12-4449-2012, 2012.

Mann, G. W., Carslaw, K. S., Reddington, C. L., Pringle, K. J., Schulz, M., Asmi, A., Spracklen, D. V., Ridley, D. A., Woodhouse, M. T., Lee, L. A., Zhang, K., Ghan, S. J., Easter, R. C., Liu, X., Stier, P., Lee, Y. H., Adams, P. J., Tost, H., Lelieveld, J., Bauer, S. E., Tsigaridis, K., van Noije, T. P. C., Strunk, A., Vignati, E., Bellouin, N., Dalvi, M., Johnson, C. E., Bergman, T., Kokkola, H., von Salzen, K., Yu, F., Luo, G., Petzold, A., Heintzenberg, J., Clarke, A., Ogren, J. A., Gras, J., Baltensperger, U., Kaminski, U., Jennings, S. G., O’Dowd, C. D., Harrison, R. M., Beddows, D. C. S., Kulmala, M., Viisanen, Y., Ulevicius, V., Mihalopoulos, N., Zdimal, V., Fiebig, M., Hansson, H.-C., Swietlicki, E., and Henzing, J. S.: Intercomparison and evaluation of global aerosol microphysical properties among AeroCom models of a range of complexity, Atmos. Chem. Phys., 14, 4679-4713, https://doi.org/10.5194/acp-14-4679-2014, 2014.

Marinescu, P. J., Heever, S. C. v. d., Saleeby, S. M., Kreidenweis, S. M., and DeMott, P. J.: The Microphysical Roles of Lower-Tropospheric versus Midtropospheric Aerosol Particles in Mature-Stage MCS Precipitation, J. Atmos. Sci., 74, 3657-3678, https://doi.org/10.1175/jas-d-16-0361.1, 2017.

Martin, S., Mei, F., Alexander, L., Artaxo, P., Barbosa, H., Bartholomew, M. J., Biscaro, T., Buseck, P., Chand, D., Comstock, J., Dubey, M., Godstein, A., Guenther, A., Hubbe, J., Jardine, K., Jimenez, J.-L., Kim, S., Kuang, C., Laskin, A., Long, C., Paralovo, S., Petäjä, T., Powers, H., Schumacher, C., Sedlacek, A., Senum, G., Smith, J., Shilling, J., Springston, S., Thayer, M., Tomlinson, J., Wang, J. and Xie, S.: Campaign datasets for Observations and Modeling of the Green Ocean Amazon (GOAMAZON), https://doi.org/10.5439/1346559, 2016.

McNaughton, C. S., Clarke, A. D., Howell, S. G., Moore, K. G., Brekhovskikh, V., Weber, R. J., Orsini, D. A., Covert, D. S., Buzorius, G., Brechtel, F. J., Carmichael, G. R., Tang, Y., Eisele, F. L., Mauldin, R. L., Bandy, A. R., Thornton, D. C., and Blomquist, B.: Spatial distribution and size evolution of particles in Asian outflow: Significance of primary and secondary aerosols during ACE-Asia and TRACE-P, J. Geophys. Res., 109, D19S06, https://doi.org/10.1029/2003jd003528, 2004

Minikin, A., Petzold, A., Ström, J., Krejci, R., Seifert, M., Velthoven, P. v., Schlager, H., and Schumann, U.: Aircraft observations of the upper tropospheric fine particle aerosol in the Northern and Southern Hemispheres at midlatitudes, Geophys. Res. Lett., 30, 1503, https://doi.org/10.1029/2002gl016458, 2003

Mulcahy, J. P., Jones, C., Sellar, A., Johnson, B., Boutle, I. A., Jones, A., Andrews, T., Rumbold, S. T., Mollard, J., Bellouin,
N., Johnson, C. E., Williams, K. D., Grosvenor, D. P., and McCoy, D. T.: Improved Aerosol Processes and Effective Radiative Forcing in HadGEM3 and UKESM1, J. Adv. Model. Earth Syst., 10, 2786-2805, https://doi.org/10.1029/2018ms001464, 2018.

Neubauer, D., Ferrachat, S., Siegenthaler-Le Drian, C., Stier, P., Partridge, D. G., Tegen, I., Bey, I., Stanelle, T., Kokkola, H., and Lohmann, U.: The global aerosol-climate model ECHAM6.3HAM2.3 - Part 2: Cloud evaluation, aerosol radiative forcing, and climate sensitivity, Geosci. Model Dev., 12, 3609-3639, https://doi.org/10.5194/gmd-12-3609-2019, 2019.

Nordeng, T. E.: Extended versions of the convective parametrization scheme at ECMWF and their impact on the mean and transient activity of the model in the tropics, Research Department Technical Memorandum, 206, 1-41, available at: https://www.ecmwf.int/en/elibrary/11393-extended-versionsconvective-parametrization-scheme (last access: 1 March 2019), 1994.

Palmer, P. I., Parrington, M., Lee, J. D., Lewis, A. C., Rickard, A. R., Bernath, P. F., Duck, T. J., Waugh, D. L., Tarasick, D. W., Andrews, S., Aruffo, E., Bailey, L. J., Barrett, E., Bauguitte, S. J.-B., Curry, K. R., Di Carlo, P., Chisholm, L., Dan, L., Forster, G., Franklin, J. E., Gibson, M. D., Griffin, D., Helmig, D., Hopkins, J. R., Hopper, J. T., Jenkin, M. E., Kindred, D., Kliever, J., Le Breton, M., Matthiesen, S., Maurice, M., Moller, S., Moore, D. P., Oram, D. E., O'Shea, S. J., Owen, R. C., Pagniello, C. M. L. S., Pawson, S., Percival, C. J., Pierce, J. R., Punjabi, S., Purvis, R. M., Remedios, J. J., Rotermund, K. M., Sakamoto, K. M., da Silva, A. M., Strawbridge, K. B., Strong, K., Taylor, J., Trigwell, R., Tereszchuk, K. A., Walker, K. A., Weaver, D., Whaley, C., and Young, J. C.: Quantifying the impact of BOReal forest fires on Tropospheric oxidants over the Atlantic using Aircraft and Satellites (BORTAS) experiment: design, execution and science overview, Atmos. Chem. Phys., 13, 6239-6261, https://doi.org/10.5194/acp-13-6239-2013, 2013.

Pappalardo, G., Amodeo, A., Apituley, A., Comeron, A., Freudenthaler, V., Linné, H., Ansmann, A., Bösenberg, J., D’Amico, G., Mattis, I., Mona, L., Wandinger, U., Amiridis, V., AladosArboledas, L., Nicolae, D., and Wiegner, M.: EARLINET: towards an advanced sustainable European aerosol lidar network, Atmos. Meas. Tech., 7, 2389-2409, https://doi.org/10.5194/amt7-2389-2014, 2014.

Park, S. and Allen, R. J.: Understanding influences of convective transport and removal processes on aerosol vertical distribution, Geophys. Res. Lett., 42, 10438-410444, https://doi.org/10.1002/2015g1066175, 2015.

Parrish, D. D., Allen, D. T., Bates, T. S., Estes, M., Fehsenfeld, F. C., Feingold, G., Ferrare, R., Hardesty, R. M., Meagher, J. F., Nielsen-Gammon, J. W., Pierce, R. B., Ryerson, T. B., Seinfeld, J. H., and Williams, E. J.: Overview of the Second Texas Air Quality Study (TexAQS II) and the Gulf of Mexico Atmospheric Composition and Climate Study (GoMACCS), J. Geophys. Res.-Atmos. (1984-2012), 114, D00F13, https://doi.org/10.1029/2009jd011842, 2009.

Reddington, C. L., McMeeking, G., Mann, G. W., Coe, H., Frontoso, M. G., Liu, D., Flynn, M., Spracklen, D. V., and Carslaw, K. S.: The mass and number size distributions of black carbon aerosol over Europe, Atmos. Chem. Phys., 13, 4917-4939, https://doi.org/10.5194/acp-13-4917-2013, 2013. 
Reddington, C. L., Carslaw, K. S., Stier, P., Schutgens, N., Coe, H., Liu, D., Allan, J., Browse, J., Pringle, K. J., Lee, L. A., Yoshioka, M., Johnson, J. S., Regayre, L. A., Spracklen, D. V., Mann, G. W., Clarke, A., Hermann, M., Henning, S., Wex, H., Kristensen, T. B., Leaitch, W. R., Pöschl, U., Rose, D., Andreae, M. O., Schmale, J., Kondo, Y., Oshima, N., Schwarz, J. P., Nenes, A., Anderson, B., Roberts, G. C., Snider, J. R., Leck, C., Quinn, P. K., Chi, X., Ding, A., Jimenez, J. L., and Zhang, Q.: THE GLOBAL AEROSOL SYNTHESIS AND SCIENCE PROJECT (GASSP): Measurements and modelling to reduce uncertainty, B. Am. Meteorol. Soc., 98, 1857-1877, https://doi.org/10.1175/bams-d-15-00317.1, 2017.

Regayre, L. A., Johnson, J. S., Yoshioka, M., Pringle, K. J., Sexton, D. M. H., Booth, B. B. B., Lee, L. A., Bellouin, N., and Carslaw, K. S.: Aerosol and physical atmosphere model parameters are both important sources of uncertainty in aerosol ERF, Atmos. Chem. Phys., 18, 9975-10006, https://doi.org/10.5194/acp18-9975-2018, 2018.

Reutter, P., Su, H., Trentmann, J., Simmel, M., Rose, D., Gunthe, S. S., Wernli, H., Andreae, M. O., and Pöschl, U.: Aerosol- and updraft-limited regimes of cloud droplet formation: influence of particle number, size and hygroscopicity on the activation of cloud condensation nuclei (CCN), Atmos. Chem. Phys., 9, 70677080, https://doi.org/10.5194/acp-9-7067-2009, 2009.

Roberts, G. C. and Nenes, A.: A Continuous-Flow Streamwise Thermal-Gradient CCN Chamber for Atmospheric Measurements, Aerosol Sci. Technol., 39, 206-221, https://doi.org/10.1080/027868290913988, 2010.

Russell, L. M., Zhang, S.-H., Flagan, R. C., Seinfeld, J. H., Stolzenburg, M. R., and Caldow, R.: Radially Classified Aerosol Detector for Aircraft-Based Submicron Aerosol Measurements, J. Atmos. Ocean. Technol., 13, 598-609, https://doi.org/10.1175/15200426(1996)013<0598:RCADFA>2.0.CO;2, 1996.

Ryerson, T. B., Andrews, A. E., Angevine, W. M., Bates, T. S., Brock, C. A., Cairns, B., Cohen, R. C., Cooper, O. R., de Gouw, J. A., Fehsenfeld, F. C., Ferrare, R. A., Fischer, M. L., Flagan, R. C., Goldstein, A. H., Hair, J. W., Hardesty, R. M., Hostetler, C. A., Jimenez, J. L., Langford, A. O., McCauley, E., McKeen, S. A., Molina, L. T., Nenes, A., Oltmans, S. J., Parrish, D. D., Pederson, J. R., Pierce, R. B., Prather, K., Quinn, P. K., Seinfeld, J. H., Senff, C. J., Sorooshian, A., Stutz, J., Surratt, J. D., Trainer, M., Volkamer, R., Williams, E. J., and Wofsy, S. C.: The 2010 California Research at the Nexus of Air Quality and Climate Change (CalNex) field study, J. Geophys. Res.-Atmos., 118, 5830-5866, https://doi.org/10.1002/jgrd.50331, 2013.

Samset, B. H., Myhre, G., Schulz, M., Balkanski, Y., Bauer, S., Berntsen, T. K., Bian, H., Bellouin, N., Diehl, T., Easter, R. C., Ghan, S. J., Iversen, T., Kinne, S., Kirkevåg, A., Lamarque, J.-F., Lin, G., Liu, X., Penner, J. E., Seland, Ø., Skeie, R. B., Stier, P., Takemura, T., Tsigaridis, K., and Zhang, K.: Black carbon vertical profiles strongly affect its radiative forcing uncertainty, Atmos. Chem. Phys., 13, 2423-2434, https://doi.org/10.5194/acp13-2423-2013, 2013.

Satheesh, S. K., Vinoj, V., and Moorthy, K. K.: Vertical distribution of aerosols over an urban continental site in India inferred using a micro pulse lidar, Geophys. Res. Lett., 33, L20816, https://doi.org/10.1029/2006gl027729, 2006.
Schutgens, N. A. J. and Stier, P.: A pathway analysis of global aerosol processes, Atmos. Chem. Phys., 14, 11657-11686, https://doi.org/10.5194/acp-14-11657-2014, 2014.

Schutgens, N. A. J., Gryspeerdt, E., Weigum, N., Tsyro, S., Goto, D., Schulz, M., and Stier, P.: Will a perfect model agree with perfect observations? The impact of spatial sampling, Atmos. Chem. Phys., 16, 6335-6353, https://doi.org/10.5194/acp-166335-2016, 2016.

Schwarz, J. P., Spackman, J. R., Gao, R. S., Watts, L. A., Stier, P., Schulz, M., Davis, S. M., Wofsy, S. C., and Fahey, D. W.: Global-scale black carbon profiles observed in the remote atmosphere and compared to models, Geophys. Res. Lett., 37, L18812, https://doi.org/10.1029/2010GL044372, 2010.

Seinfeld, J. H. and Pandis, S. N.: "Atmospheric chemistry and physics: from air pollution to climate change”, Wiley, 2016.

Shinozuka, Y. and Redemann, J.: Horizontal variability of aerosol optical depth observed during the ARCTAS airborne experiment, Atmos. Chem. Phys., 11, 8489-8495, https://doi.org/10.5194/acp-11-8489-2011, 2011.

Shrivastava, M., Easter, R. C., Liu, X., Zelenyuk, A., Singh, B., Zhang, K., Ma, P. L., Chand, D., Ghan, S., Jimenez, J. L., Zhang, Q., Fast, J., Rasch, P. J., and Tiitta, P.: Global transformation and fate of SOA: Implications of low-volatility SOA and gas-phase fragmentation reactions, J. Geophys. Res.-Atmos., 120, 41694195, https://doi.org/10.1002/2014jd022563, 2015.

Singh, H. B., Brune, W. H., Crawford, J. H., Flocke, F., and Jacob, D. J.: Chemistry and transport of pollution over the Gulf of Mexico and the Pacific: spring 2006 INTEX-B campaign overview and first results, Atmos. Chem. Phys., 9, 2301-2318, https://doi.org/10.5194/acp-9-2301-2009, 2009.

Slinn, S. and Slinn, W.: Predictions for particle deposition on natural waters, Atmos. Environ, (1967) 14, 1013-1016, https://doi.org/10.1016/0004-6981(80)90032-3, 1980.

Snider, J. R., Petters, M. D., Wechsler, P., and Liu, P. S. K.: Supersaturation in the Wyoming CCN Instrument, J. Atmos. Ocean. Technol., 23, 1323-1339, https://doi.org/10.1175/jtech1916.1, 2006.

Spracklen, D. V., Pringle, K. J., Carslaw, K. S., Mann, G. W., Manktelow, P., and Heintzenberg, J.: Evaluation of a global aerosol microphysics model against size-resolved particle statistics in the marine atmosphere, Atmos. Chem. Phys., 7, 2073-2090, https://doi.org/10.5194/acp-7-2073-2007, 2007.

Stevens, B., Giorgetta, M., Esch, M., Mauritsen, T., Crueger, T.,Rast, S., Salzmann, M., Schmidt, H., Bader, J., Block, K., Brokopf, R., Fast, I., Kinne, S., Kornblueh, L., Lohmann, U., Pincus, R., Reichler, T., and Roeckner, E.: Atmospheric component of the MPI-M Earth System Model: ECHAM6, J. Adv. Model. Earth Sy., 5, 146-172, https://doi.org/10.1002/jame.20015, 2013.

Stier, P., Feichter, J., Kinne, S., Kloster, S., Vignati, E., Wilson, J., Ganzeveld, L., Tegen, I., Werner, M., Balkanski, Y., Schulz, M., Boucher, O., Minikin, A., and Petzold, A.: The aerosol-climate model ECHAM5-HAM, Atmos. Chem. Phys., 5, 1125-1156, https://doi.org/10.5194/acp-5-1125-2005, 2005.

Sundqvist, H., Berge, E., and Kristjánsson, J. E.: Condensation and Cloud Parameterization Studies with a Mesoscale Numerical Weather Prediction Model, Mon. Weather Rev., 117, 1641-1657, https://doi.org/10.1175/15200493(1989)117<1641:CACPSW>2.0.CO;2, 1989. 
Tegen, I., Neubauer, D., Ferrachat, S., Siegenthaler-Le Drian, C., Bey, I., Schutgens, N., Stier, P., Watson-Parris, D., Stanelle, T., Schmidt, H., Rast, S., Kokkola, H., Schultz, M., Schroeder, S., Daskalakis, N., Barthel, S., Heinold, B., and Lohmann, U.: The global aerosol-climate model ECHAM6.3-HAM2.3 - Part 1: Aerosol evaluation, Geosci. Model Dev., 12, 1643-1677, https://doi.org/10.5194/gmd-12-1643-2019, 2019.

Textor, C., Schulz, M., Guibert, S., Kinne, S., Balkanski, Y., Bauer, S., Berntsen, T., Berglen, T., Boucher, O., Chin, M., Dentener, F., Diehl, T., Easter, R., Feichter, H., Fillmore, D., Ghan, S., Ginoux, P., Gong, S., Grini, A., Hendricks, J., Horowitz, L., Huang, P., Isaksen, I., Iversen, I., Kloster, S., Koch, D., Kirkevåg, A., Kristjansson, J. E., Krol, M., Lauer, A., Lamarque, J. F., Liu, X., Montanaro, V., Myhre, G., Penner, J., Pitari, G., Reddy, S., Seland, Ø., Stier, P., Takemura, T., and Tie, X.: Analysis and quantification of the diversities of aerosol life cycles within AeroCom, Atmos. Chem. Phys., 6, 1777-1813, https://doi.org/10.5194/acp-6-17772006, 2006.

Tie, X., Madronich, S., Li, G., Ying, Z., Weinheimer, A., Apel, E., and Campos, T.: Simulation of Mexico City plumes during the MIRAGE-Mex field campaign using the WRF-Chem model, Atmos. Chem. Phys., 9, 4621-4638, https://doi.org/10.5194/acp-94621-2009, 2009.

Tiedtke, M.: A Comprehensive Mass Flux Scheme for $\mathrm{Cu}$ mulus Parameterization in Large-Scale Models, Mon. Weather Rev., 117, 1779-1800, https://doi.org/10.1175/15200493(1989)117<1779:ACMFSF>2.0.CO;2, 1989

Toon, O. B., Maring, H., Dibb, J., Ferrare, R., Jacob, D. J., Jensen, E. J., Luo, Z. J., Mace, G. G., Pan, L. L., Pfister, L., Rosenlof, K. H., Redemann, J., Reid, J. S., Singh, H. B., Thompson, A. M., Yokelson, R., Minnis, P., Chen, G., Jucks, K. W. and Pszenny, A.: Planning, implementation, and scientific goals of the Studies of Emissions and Atmospheric Composition, Clouds and Climate Coupling by Regional Surveys (SEAC4RS) field mission, J. Geophys. Res.-Atmos., 121, 49675009, https://doi.org/10.1002/2015JD024297, 2016.

Tsigaridis, K., Daskalakis, N., Kanakidou, M., Adams, P. J., Artaxo, P., Bahadur, R., Balkanski, Y., Bauer, S. E., Bellouin, N., Benedetti, A., Bergman, T., Berntsen, T. K., Beukes, J. P., Bian, H., Carslaw, K. S., Chin, M., Curci, G., Diehl, T., Easter, R. C., Ghan, S. J., Gong, S. L., Hodzic, A., Hoyle, C. R., Iversen, T., Jathar, S., Jimenez, J. L., Kaiser, J. W., Kirkevåg, A., Koch, D., Kokkola, H., Lee, Y. H., Lin, G., Liu, X., Luo, G., Ma, X., Mann, G. W., Mihalopoulos, N., Morcrette, J.-J., Müller, J.-F., Myhre, G., Myriokefalitakis, S., Ng, N. L., O’Donnell, D., Penner, J. E., Pozzoli, L., Pringle, K. J., Russell, L. M., Schulz, M., Sciare, J., Seland, Ø., Shindell, D. T., Sillman, S., Skeie, R. B., Spracklen, D., Stavrakou, T., Steenrod, S. D., Takemura, T., Tiitta, P., Tilmes, S., Tost, H., van Noije, T., van Zyl, P. G., von Salzen, K., Yu, F., Wang, Z., Wang, Z., Zaveri, R. A., Zhang, H., Zhang, K., Zhang, Q., and Zhang, X.: The AeroCom evaluation and intercomparison of organic aerosol in global models, Atmos. Chem. Phys., 14, 10845-10895, https://doi.org/10.5194/acp-1410845-2014, 2014.

Twohy, C. H., Hudson, J. G., Yum, S.-S., Anderson, J. R., Durlak, S. K., and Baumgardner, D.: Characteristics of cloud-nucleating aerosols in the Indian Ocean region, J. Geophys. Res.-Atmos., 106, 28699-28710, https://doi.org/10.1029/2000JD900779, 2001.
Vignati, E., Wilson, J., and Stier, P.: M7: An efficient size-resolved aerosol microphysics module for large-scale aerosol transport models, J. Geophys. Res., 109, D22202, https://doi.org/10.1029/2003jd004485, 2004.

Walker, H. M., Stone, D., Ingham, T., Vaughan, S., Cain, M., Jones, R. L., Kennedy, O. J., McLeod, M., Ouyang, B., Pyle, J., Bauguitte, S., Bandy, B., Forster, G., Evans, M. J., Hamilton, J. F., Hopkins, J. R., Lee, J. D., Lewis, A. C., Lidster, R. T., Punjabi, S., Morgan, W. T., and Heard, D. E.: Night-time measurements of $\mathrm{HO}_{x}$ during the RONOCO project and analysis of the sources of $\mathrm{HO}_{2}$, Atmos. Chem. Phys., 15, 8179-8200, https://doi.org/10.5194/acp-15-8179-2015, 2015.

Watson-Parris, D., Schutgens, N., Cook, N., Kipling, Z., Kershaw, P., Gryspeerdt, E., Lawrence, B., and Stier, P.: Community Intercomparison Suite (CIS) v1.4.0: a tool for intercomparing models and observations, Geosci. Model Dev., 9, 3093-3110, https://doi.org/10.5194/gmd-9-3093-2016, 2016.

Watson-Parris, D., Schutgens, N., Winker, D., Burton, S. P., Ferrare, R. A., and Stier, P.: On the Limits of CALIOP for Constraining Modeled Free Tropospheric Aerosol, Geophys. Res. Lett., 45, 9260-9266, https://doi.org/10.1029/2018gl078195, 2018.

Wiedensohler, A.: An Approximation of the Bipolar ChargeDistribution for Particles in the Sub-Micron Size Range, J. Aerosol. Sci., 19, 387-389, https://doi.org/10.1016/00218502(88)90278-9, 1988.

Wiedensohler, A., Birmili, W., Nowak, A., Sonntag, A., Weinhold, K., Merkel, M., Wehner, B., Tuch, T., Pfeifer, S., Fiebig, M., Fjäraa, A. M., Asmi, E., Sellegri, K., Depuy, R., Venzac, H., Villani, P., Laj, P., Aalto, P., Ogren, J. A., Swietlicki, E., Williams, P., Roldin, P., Quincey, P., Hüglin, C., Fierz-Schmidhauser, R., Gysel, M., Weingartner, E., Riccobono, F., Santos, S., Grüning, C., Faloon, K., Beddows, D., Harrison, R., Monahan, C., Jennings, S. G., O’Dowd, C. D., Marinoni, A., Horn, H.-G., Keck, L., Jiang, J., Scheckman, J., McMurry, P. H., Deng, Z., Zhao, C. S., Moerman, M., Henzing, B., de Leeuw, G., Löschau, G., and Bastian, S.: Mobility particle size spectrometers: harmonization of technical standards and data structure to facilitate high quality long-term observations of atmospheric particle number size distributions, Atmos. Meas. Tech., 5, 657-685, https://doi.org/10.5194/amt-5-657-2012, 2012.

Winker, D. M., Vaughan, M. A., Omar, A., Hu, Y., Powell, K. A., Liu, Z., Hunt, W. H., and Young, S. A.: Overview of the CALIPSO Mission and CALIOP Data Processing Algorithms, J. Atmos. Ocean. Technol., 26, 2310-2323, https://doi.org/10.1175/2009jtecha1281.1, 2009.

Winker, D. M., Tackett, J. L., Getzewich, B. J., Liu, Z., Vaughan, M. A., and Rogers, R. R.: The global 3-D distribution of tropospheric aerosols as characterized by CALIOP, Atmos. Chem. Phys., 13, 3345-3361, https://doi.org/10.5194/acp-133345-2013, 2013.

Wofsy, S. C., Afshar, S., Allen, H. M., Apel, E., Asher, E. C., Barletta, B., Bent, J., Bian, H., Biggs, B. C., Blake, D. R., Blake, N., Bourgeois, I., Brock, C. A., Brune, W. H., Budney, J. W., Bui, T. P., Butler, A., Campuzano-Jost, P., Chang, C. S., Chin, M., Commane, R., Correa, G., Crounse, J. D., Cullis, P. D., Daube, B. C., Day, D. A., Dean-Day, J. M., Dibb, J. E., DiGangi, J. P., Diskin, G. S., Dollner, M., Elkins, J. W., Erdesz, F., Fiore, A. M., Flynn, C. M., Froyd, K., Gesler, D. W., Hall, S. R., Hanisco, T. F., Hannun, R. A., Hills, A. J., Hintsa, E. 
J., Hoffman, A., Hornbrook, R. S., Huey, L. G., Hughes, S., Jimenez, J. L., Johnson, B. J., Katich, J. M., Keeling, R. F., Kim, M. J., Kupc, A., Lait, L. R., Lamarque, J.-F., Liu, J., McKain, K., Mclaughlin, R. J., Meinardi, S., Miller, D. O., Montzka, S. A., Moore, F. L., Morgan, E. J., Murphy, D. M., Murray, L. T., Nault, B. A., Neuman, J. A.,Newman, P. A., Nicely, J. M., Pan, X., Paplawsky, W., Peischl, J., Prather, M. J., Price, D. J., Ray, E., Reeves, J. M., Richardson, M., Rollins, A. W., Rosenlof, K. H., Ryerson, T. B., Scheuer, E., Schill, G. P., Schroder, J. C., Schwarz, J. P., St.Clair, J. M., Steenrod, S. D., Stephens, B. B., Strode, S. A., Sweeney, C., Tanner, D., Teng, A. P., Thames, A. B., Thompson, C. R., Ullmann, K., Veres, P. R., Vieznor, N., Wagner, N. L., Watt, A., Weber, R., Weinzierl, B., Wennberg, P., Williamson, C. J., Wilson, J. C., Wolfe, G. M., Woods, C. T., and Zeng, L. H.: ATom: Merged Atmospheric Chemistry, Trace Gases, and Aerosols, ORNL DAAC, Oak Ridge, Tennessee, USA, https://doi.org/10.3334/ORNLDAAC/1581, 2018.

Wood, R., Mechoso, C. R., Bretherton, C. S., Weller, R. A., Huebert, B., Straneo, F., Albrecht, B. A., Coe, H., Allen, G., Vaughan, G., Daum, P., Fairall, C., Chand, D., Gallardo Klenner, L., Garreaud, R., Grados, C., Covert, D. S., Bates, T. S., Krejci, R., Russell, L. M., de Szoeke, S., Brewer, A., Yuter, S. E., Springston, S. R., Chaigneau, A., Toniazzo, T., Minnis, P., Palikonda, R., Abel, S. J., Brown, W. O. J., Williams, S., Fochesatto, J., Brioude, J., and Bower, K. N.: The VAMOS Ocean-Cloud-AtmosphereLand Study Regional Experiment (VOCALS-REx): goals, platforms, and field operations, Atmos. Chem. Phys., 11, 627-654, https://doi.org/10.5194/acp-11-627-2011, 2011.
Young, G., Jones, H. M., Darbyshire, E., Baustian, K. J., McQuaid, J. B., Bower, K. N., Connolly, P. J., Gallagher, M. W., and Choularton, T. W.: Size-segregated compositional analysis of aerosol particles collected in the European Arctic during the ACCACIA campaign, Atmos. Chem. Phys., 16, 4063-4079, https://doi.org/10.5194/acp-16-4063-2016, 2016.

Yu, F., Wang, Z., Luo, G., and Turco, R.: Ion-mediated nucleation as an important global source of tropospheric aerosols, Atmos. Chem. Phys., 8, 2537-2554, https://doi.org/10.5194/acp-8-25372008, 2008.

Zhang, K., O’Donnell, D., Kazil, J., Stier, P., Kinne, S., Lohmann, U., Ferrachat, S., Croft, B., Quaas, J., Wan, H., Rast, S., and Feichter, J.: The global aerosol-climate model ECHAM-HAM, version 2: sensitivity to improvements in process representations, Atmos. Chem. Phys., 12, 8911-8949, https://doi.org/10.5194/acp-12-8911-2012, 2012.

Zhang, S.-H., Akutsu, Y., Russell, L. M., Flagan R. C., and Seinfeld, J. H.: Radial Differential Mobility Analyzer, Aerosol Sci. Technol., 23, 357-372, https://doi.org/10.1080/02786829508965320, 1995.

Zuidema, P., Redemann, J., Haywood, J., Wood, R., Piketh, S., Hipondoka, M., and Formenti, P.: Smoke and Clouds above the Southeast Atlantic: Upcoming Field Campaigns Probe Absorbing Aerosol's Impact on Climate, B. Am. Meteorol. Soc., 97, 1131-1135, https://doi.org/10.1175/bams-d-15-00082.1, 2016. 